\title{
INSERÇÃO DO GENE PR5K EM CANA-DE-AÇÚCAR VISANDO INDUZIR RESISTÊNCIA AO FUNGO DA FERRUGEM
}

\author{
Puccinia melanocephala
}

\section{ROSANA DE FÁTIMA ZAROTTISACILOTO}

\begin{abstract}
Dissertação apresentada à Escola Superior de Agricultura "Luiz de Queiroz", Universidade de São Paulo, para obtenção do título de Mestre em Ciências, Área de Concentração: Fisiologia e Bioquímica de Plantas.
\end{abstract}

PIRACICABA

Estado de São Paulo - Brasil

Junho- 2003 


\title{
INSERÇÃO DO GENE PR5K EM CANA-DE-AÇÚCAR VISANDO INDUZIR RESISTÊNCIA AO FUNGO DA FERRUGEM Puccinia melanocephala
}

\section{ROSANA DE FÁTIMA ZAROTTI SACILOTO}

Bióloga

Orientador: Prof. Dr.LUIZ ANTONIO GALLO

\begin{abstract}
Dissertação apresentada à Escola Superior de Agricultura "Luiz de Queiroz", Universidade de São Paulo, para obtenção do título de Mestre em Ciências Área de Concentração: Fisiologia e Bioquímica de Plantas.
\end{abstract}

PIRACICABA

Estado de São Paulo - Brasil

Junho- 2003 


\section{Dados Internacionais de Catalogação na Publicação (CIP)} DIVISÃO DE BIBLIOTECA E DOCUMENTAÇÃO - ESALQ/USP

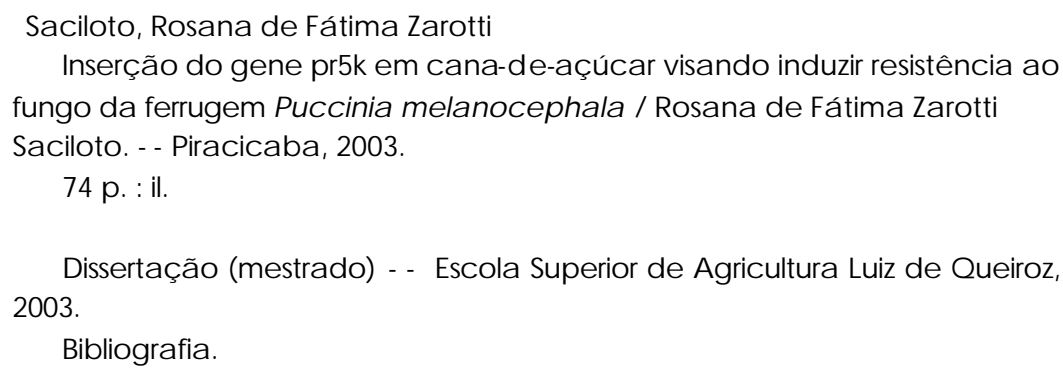

1. Biolística 2. Cana-d e-açúcar3. Femugem (Doença de planta) 4. Fungos fitopagênic os 5. Genes6. Plantas transgênicas 7. Resistência genética vegeta I. Título

CDD 633.61 
Ao meu pai Francisco (in me mória) minha mãe, Atlântica Maria, que de uma forma muito especial me incentivou e apoiou,

OFEREÇO.

Ao meu marido, Antônio Carlos e aos meus filhos, Guilherme, Ana Ligia; Ricardo pela compreensão; amor e de dic ação recebidos,

DEDICO 


\section{AGRADECIMENTOS}

Agradeço a DEUS pelo Dom da vida ,coragem, tranqüilidade, sem a qual eu nada seria, pois muitas vezes que fraquejei ele estava presente me erguendo com seu amor.

Agradeço a todas as pessoas que, de forma direta ou indireta, contribuíram para a realização deste trabalho, especialmente:

Ao Prof. Dr. Luiz Antonio Gallo pela orientação, amizade e incentivo e também pela paciência durante a realização deste trabalho e no decorrer do curso.

Aos meus familiares que de um modo indireto me auxiliaram, tentando compreender a minha ausência, me incentivando a nunca desistir.

Ao Dr. Otto J. Crocomo pela amizade, carinho ao longo destes anos.

À Profa. Dra. Helaine Carrer pelo apoio na elaboração da pesquisa

Ao Prof. Dr. Murilo de Melo pela amizade, dedicação e valioso apoio durante a elaboração da pesquisa. 
Ao Dr. Eugênio Ullian, pela ajuda, orientação e amizade durante a realização do projeto pesquisa.

As pesquisadoras Maria Cristina Falco, Sabrina, Noemi e Vicente do Centro de Tecnologia - CTC - Copersucar, pelo apoio, amizade, dedicação e paciência no decorrer de todos esses anos ajudando na elaboração do projeto.

Ao Biólogo. Enio Thiago de Oliveira pela paciência, amizade e compreensão.

Ao colega Romeu Rocha pela dedicação e amizade.

As colegas Patrícia Ross; Tatiana; Flávia; Daiane; Natalia; Marcela; Guilherme; Gustavo; Beto; do laboratório de Marcadores Moleculares e Micropropagação pela amizade, carinho e compreensão no decorrer do ano e na elaboração do projeto.

Aos colegas de laboratório de Biologia Molecular de Plantas, Irving Berger; Clara Pestana; Valesca Pandolfi; Fátima Valentina; Raquel Helena B. Lordello; Adriano, Danila, Simoni pelo apoio, compreensão, amizade, ensinamentos e incentivo em to dos os momentos.

Ao curso de Fisiologia e Bioquímica de Plantas, e seu corpo docente pelos ensinamentos.

Aos meus amigos do Curso de Fisiologia e Bioquímica de Plantas, Amanda, Liliane, Antonio Francisco Amaral, Maria Carolina, Joana, Marisa muito obrigada pelo apoio nos momentos mais difíceis onde pude contar com vocês. 
A CAPEs, pela concessão da bolsa de estudos.

A todos os professores, alunos e funcionários do Departamento de Ciências Biológicas ESALQ - USP

Aos funcionários do Setor de Biblioteca Central.

Aos meus amigos fora dos meus âmbitos laboratoriais mais que direta e indiretamente me apoiaram, incentivaram dando forças, erguendo-me nos momentos que pensei em fraquejar, a eles meu muito obrigado por terem sido meus verdadeiros amigos.

A todos os meus sinceros agradecimentos 


\section{SUMÁRIO}

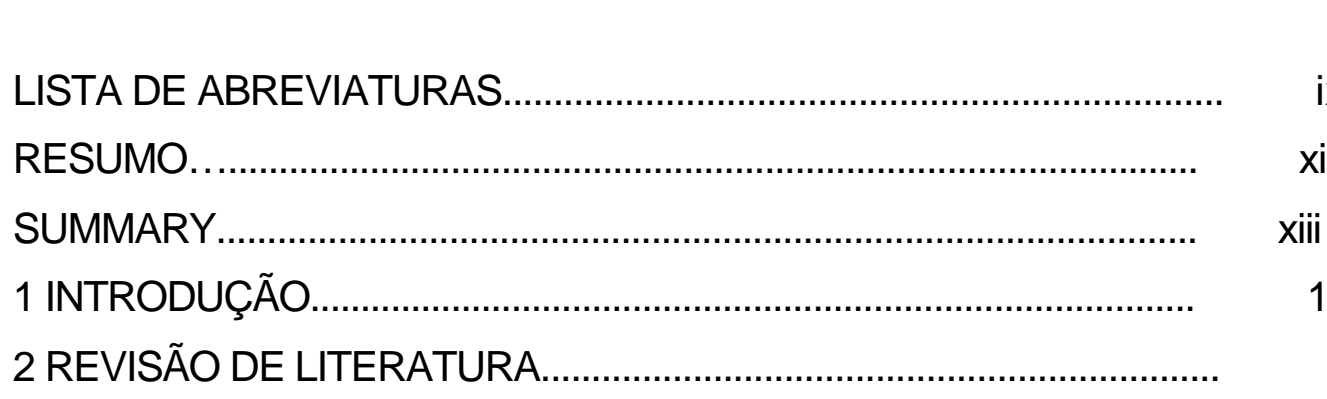

2.1 A Cana-de-açúcar e a importância econômica..................................... 5

2.2 Doenças da cana-de-açúcar................................................................ 8

2.2.1 Ferrugem - Fungo Puccinia melanocephala.................................... 9

2.2.2 Interação planta x patógeno........................................................... 11

2.2.3 A cana-de-açúcar e era genômica.................................................. 14

2.3 Transformação genética..................................................................... 19

2.3.1 Transformação da cana-de-açúcar............................................... 22

2.3.2 A escolha do alvo.......................................................................... 24

2.3.3 Seleção dos transformantes........................................................... 24

2.3.4 Escolha do promotor................................................................... 26

2.3.5 Escolha do transgene.................................................................. 27

2.3.6 Analises moleculares do material transformante............................ $\quad 27$

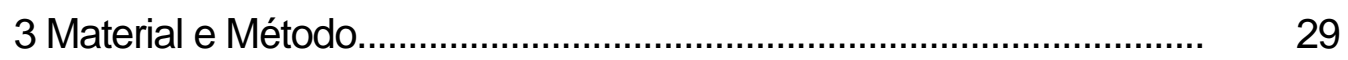

3.1 Fenologia da cana-de-açúcar......................................................... 29

3.1.1 Material Vegetal........................................................................... 30

3.2 Obtenção dos Calos....................................................................... 30

3.3 Plasmídios pAHC17, pXL3 e pHA9................................................ 32 
3.3.1 Digestão dos Plasmídios pAHC17 e pXL3 com as enzimas de restrições BamHI e EcoRI................................................................... 35

3.4 Clonagem do inserto no Vetor...................................................... 36

3.4.1 Preparação das partículas de tungstênio para o bombardeamento. $\quad 37$

3.5 Escolha da fase de subcultivo para bombardeamento....................... 38

3.6 Aparelho de biobalistica............................................................. 39

3.7 Regeneração das Plantas........................................................... 39

3.8 Preparo do DNA da planta(Miniprep)............................................. 40

3.9 Análise da integração porPCR ..................................................... 41

4 RESULTADOS ........................................................................... 43

4.1 Material vegetal obtido em casa de vegetação.................................... 43

4.2 Cultura de tecido para cana-de-açúcar.............................................. 43

4.3 Plasmídios...................................................................................... 46

4.4 Confirmação da inserção do pr5k no vetor pAHC17.......................... 48

4.5 Bombardeamento dos calos embriogênicos de cana-de-açúcar.......... 50

4.6 Otimização do protocolo para bombardeamento................................ 51

4.7 Seleção dos calos para resistência ao antibiótico geneticina............... 51

4.8 Análise do DNA - método PCR ....................................................... 56

5 CONCLUSÕES .......................................................................... 59

REFERÊNCIAS BIBLIOGRÁFICAS ...................................................... 61 


\section{LISTA DE ABREVIATURAS}

$\begin{array}{ll}\text { dNTP } & \text { deoxiribonucleotídeo trifosfato (A,T,C,G) } \\ \text { 2,4-D } & \text { ácido 2,4-diclorofenoxiacético } \\ \text { ATP } & \text { adenosina trifosfato } \\ \text { BAP } & \text { 6-benzilamino purina } \\ \text { Avr } & \text { gene de avirulência } \\ \text { DNA } & \text { ácido desoxirribonucléico } \\ \text { HR } & \text { resposta de hipersensibilidade } \\ \text { SAR } & \text { resistência sistêmica induzida } \\ \text { Kb } & \text { kilobases (1000 nucleotídeos) } \\ \text { NptII } & \text { gene da neomicina fosfotransferase II } \\ \text { CI-3Clav } & \text { Meio de cultura Cl-3 acrescido do antibiótico Clavulinß } \\ \text { CI-30S } & \text { Meio de cultura Cl-3 contendo sorbitol e manitol } \\ \text { CI-3Gen2,4-D } & \text { Meio de cultura Cl-3 contendo antibiótico Geneticina e } \\ & \text { acrescido do hormônio 2,4-D } \\ \text { CI-3GenBap } & \text { Meio de cultura contendo o antibiótico geneticina e acrescido do } \\ \text { EST } & \text { hormônio BAP (6 benzilaminopurina) } \\ \text { PCR } & \text { seqüências expressas (“Expressed Sequence Tag”) } \\ \text { PEG } & \text { reação da polimerase em cadeia } \\ \text { pAHC17 } & \text { polietileno glicol } \\ \text { gene da ubiquitina do milho ubi-1 } \\ \text { gene relacionado às proteínas PR5 } \\ \text { PX3 }\end{array}$


pHA9 gene da neomicina fosfotranferase II (NPT II)

rpm rotações por minuto

SUCEST Projeto Transcriptoma da Cana-de-açúcar

Tween polioxietilenosorbitol

$\mathbf{P b} \quad$ pares de bases

EDTA ácido etilenodiamino tetracético

DTT ditiotreitol

CaMV vírus-do-mosaico-da-couve-flor 


\title{
INSERÇÃO DO GENE PR5K EM CANA-DE-AÇÚCAR VISANDO INDUZR RESISTÊNCIA AO FUNGO DA FERRUGEM \\ Puccinia melanocephala
}

\author{
Autora: ROSANA DE FÁTIMA ZAROTTI SACILOTO \\ Orientador: Prof. Dr. LUIZ ANTONIO GALLO
}

\section{RESUMO}

A cana-de-açúcar é uma cultura de grande importância econômica para alguns paises da América especialmente para o Brasil. A mesma apresenta grandes problemas de ataque de patógenos e dentre eles destaca-se a ferrugem causada pelo fungo Puccinia melanocephala. $\mathrm{O}$ objetivo deste trabalho foi inserir um gene de resistência ao patógeno através da técnica de biolística. Calos embriogênicos de cana-de-açúcar da variedade australiana Q117 sensível à ferrugem, foram bombardeados com partículas de tungstênio revestidas com o vetor pRGA. Este vetor foi construído empregando-se 0 plasmídio pAHC17 que contém o gene da ubiquitina do milho ubi-1, que se expressa somente em monocotiledônea, o plasmídio pXL3 que contém o gene de interesse $P R 5 K$,relacionado com as PR5 proteínas, envolvida no sistema de defesa contra microorganismos patogênicos, e o plasmídio pAH9 que contém o gene neo, que confere resistência ao antibiótico geneticina. A seleção foi feita 
com o antibiótico geneticina. O plasmídio pRGA foi bombardeado em calos de cana-de-açúcar com 19 semanas, cultivadas em manitol e sorbitol 4 horas antes do bombardeamento. Após o bombardeamento, os calos foram transferidos para meio $\mathrm{Cl}-3$ onde ficaram no escuro por 10 dias. Os mesmos foram transferidos para meio CH3-2,4-D de regeneração contendo o antibiótico de seleção geneticina $(35 \mathrm{mg} / \mathrm{mL})$. Os calos selecionadas foram repicadas para meio de cultivo Cl-3BAP. As plântulas regeneradas apresentaram um percentual de $20 \%$. As mesmas foram submetidas àanálise de confirmação por PCR, empregando-se os primers D12 e E01. Pela analise do resultado do PCR, foi observado que cerca de $1 \%$ apresentou banda correspondente ao pRGA indicando possível transformação, e que várias regiões foram amplificadas em relação \&̀ analisadas. 


\title{
INSERTION OF PR5K GENE IN SUGAR CANE TO INDUCE RESISTANT PLANTS TO RUST DISEASE FUNGI Puccinia melanocephala
}

\author{
Author: ROSANA DE FÁTIMA ZAROTTI SACILOTO \\ Adviser: Prof. Dr. LUIZ ANTONIO GALLO
}

\section{SUMMARY}

The Sugar cane is very important culture for many countries especially Brazil. This culture however presents many problems with diseases; mainly rust disease that is spread mechanically and caused by Puccinia melanocephala fungi. The aim of this work was to get resistant plants with the gene PR5K , which is related to PR5 resistant proteins. Embriogenic callus of sugar cane plants Australian variety Q117 were used in shot gun procedure using tungsten particles covered by DNA from pRGA vector. The construction were made using the plasmid $\mathrm{pAHC} 17$ that contains the maize ubiquitin gene that is expressed only in monocotyledons plants, the plasmid pXL3 with PR5K gene related with PR5 proteins, involved with the defense system in plants. The new 
plasmid has part of pHA9 that contains the neo gene, which allows the plant to be resistant to geneticin used in the selection procedure. The plasmid pRGA was used for the short gum experiments. Callus with 19 weeks were transferred to manitol and sorbitol media, 4 hours before shooting. After shooting the calluses were transferred to Cl-3-2,4-D media plus geneticin antibiotic (35 $\mathrm{mg} / \mathrm{mL}$ ). The selected plants were sub cultivated in the Cl3BAP media. From the total callus used in the shot gun experiments, $20 \%$ were selected, and from this total, $1 \%$ gave positive result using the PCR procedure, indicating that the transformed plants has the pRGA plasmid. 


\section{INTRODUÇÃO}

A cana-de-açúcar é uma planta alógama que pertence à família Gramineae (Poaceae). É do gênero Saccharum, originária do Sudeste Asiático, na grande região central da Nova Guiné e Indonésia (Daniels \& Roach, 1987). Possui seis espécies dentre elas: Saccharum officinarum, S. spontaneum, S. robustum, S. sinense, S. Barbieri e $S$. edule. A maioria das variedades comerciais é formada por meio do cruzamento das várias espécies existentes $\mathrm{e}$ possui número diplóide de cromossomos, variando entre 130 a 170 .

O Brasil cultiva cana-de-açúcar desde o seu descobrimento, sendo que a cultura estabeleceu-se de forma definitiva nas regiões Centro-Sul e Nordeste do país (Carvalho, 1993). Esta é uma das gramíneas mais cultivadas nas regiões tropicais e subtropicais e, além da importância nas indústrias do açúcar e álcool, a cana-de-açúcar constitui base de produção de matérias-primas como bagaço, melaço e outros de utilização crescente (Stupiello, 1987).

A cana de açúcar é uma cultura de grande importância econômica para alguns países das Américas, especialmente para o Brasil, que apresenta a maior área cultivada e ocupa a primeira posição em produção, em termos mundiais.

Dentre os problemas que afetam a cultura, estão os inúmeros ataques de patógenos e entre eles destaca-se a ferrugem causada pelo fungo Puccinia melanocephala. As espécies com os sintomas apresentam manchas amareladas, circulares ou elípticas recobertas pela cutícula da planta.Nas plantas susceptíveis, a doença forma pústulas agrupadas formando 
placas de tecidos necrosados, e o processo fotossintético é afetado tanto pela retirada dos nutrientes quanto pela queda das folhas provocada pelo patógeno. As folhas apresentam-se sem brilho e queimadas, acarretando perdas enormes, não só pelos danos econômicos que ocasionam à agroindústria sucroalcooleira, mas também pela dificuldade do controle já que o vento é um dos agentes de maior importância na dispersão dos esporos da ferrugem a longa distância.

As alterações que constituem a resposta de defesa das plantas, por causa do estresse causado por patógenos, têm sido intensamente estudadas com o objetivo do melhoramento vegetal (Kombrink., \& Somssich., 1995; Dempsey et al., 1998). Gatehouse \& Gatehouse, (1998) demonstraram a existência de genes de resistência a patógenos, em que um simples lócus é responsável pela reação de alguns cultivos de trigo à ferrugem causada pelo $P$. striiforms $\mathrm{O}$ significado desta observação ficou evidente após a elucidação da teoria gene por gene descrita por Flor $(1956,1971)$, que demonstrou que, para muitas relações planta patógeno, a combinação entre os pares de genes de resistência da planta $(R)$ e de avirulencia (Avr) do patógeno controlam o resultado das interações, levando a planta àdoença ou àresistência.

A transformação de plantas com genes de defesa têm sido alvo de muitos estudos nos últimos anos. Diferentes genes que fazem parte do mecanismo de defesa foram clonados e introduzidos nas plantas empregando estratégias como a superexpressão ou supressão de um gene, o que permitiu a obtenção com sucesso de plantas transgênicas resistentes a diferentes patógenos (Dixon et al, 1996; Hammond-Kosack et al, 1998; Dempsey et al, 1998).

O surgimento da engenharia genética no final da década de 80 mostrou inúmeras opções atraentes para os melhoristas convencionais, que passaram a utilizar as técnicas moleculares, embora tenham surgido muitos problemas como a necessidade de promotores específicos, o silenciamento de genes e a dificuldade de transformação em monocotiledôneas por 
Agrobacterium, e a recalcitrância na regeneração de plantas a partir de protoplastos.

Mas com o passar dos anos e com o desenvolvimento de técnicas modernas de análises e manipulação genética de plantas, o melhoramento tradicional da cana-de-açúcar ganhou o suporte da biotecnologia. Isto tem proporcionado o aparecimento de soluções para problemas do melhoramento tradicional que não podem ser resolvidos através de cruzamento, seja por indisponibilidade dos genes de interesse ou por necessidade de obtenção de novas variedades em curto prazo.

A Biolística têm mostrado ser um método promissor na transformação de plantas de cana-de-açúcar. A produção de novas variedades mais produtiva e resistente a doenças tem sido a meta de muitos centros de pesquisas, como a ESALQ, Copersucar, IAC, UFSC e EMBRAPA. Assim as técnicas de biolística têm sido empregadas no processo de transformação de monocotiledôneas (Arenciba et al.,1998), visando-se obter melhor produtividade e também resistência a doenças, empregando vetores de expressão tecido-específico, como sendo o caminho para a produção de plantas resistentes a patógenos (Birch \& Franks, 1991).

Inúmeras técnicas têm sido empregadas com sucesso no melhoramento e no aumento da diversidade genética das espécies de cana-de-açúcar. Falco (1998) obteve plantas transgênicas de cana-de-açúcar, utilizando o bombardeamento com partículas envolvidas por DNA, utilizando-se genes de resistência a herbicidas como marcadores.

O objetivo deste trabalho propõe a construção de um vetor de transformação contendo o gene de interesse PR5K (receptor de proteína kinase), um gene de membrana ligado æ̀s PR proteínas que será empregado na transformação por biolística de plantas de cana-de-açúcar da variedade australiana Q117 o qual se mostrou susceptível à ferrugem, visando à produção de plantas transgênicas de cana-de-açúcar, expressando o gene PR5K resistente àFerrugem Puccinia melanocephala. 
Os objetivos deste projeto foram:

i) Inserção do gene PR5K em um vetor de transformação.

ii) Obtenção de plantas transgênicas através do bombardeamento de calos da variedade Q117.

iii) Regeneração da cana-de-açúcar após o bombardeamento.

iv) Identificação das mesmas em nível molecular, através da análise de PCR. 


\section{REVISÃO DE LITERATURA}

\subsection{A cana-de-açúcar e sua importância econômica}

Desde os tempos do Brasil colônia até os dias de hoje, a cultura de cana-de-açúcar tem sido uma grande fonte de riquezas para a economia brasileira. O Brasil é o maior produtor mundial de cana-de-açúcar com uma safra estimada em 338 milhões de toneladas em 2001, o que equivale a $27 \%$ da produção mundial. A cana-de-açúcar é cultivada em 5 milhões de hectares, com concentração no Sudeste. O Nordeste com Alagoas e Pernambuco e também Minas Gerais e Rio de Janeiro são importantes produtores contribuindo juntos com quase $30 \%$ da safra brasileira, mas é o estado de São Paulo que concentra a maioria das lavouras. Há cerca de 50 mil produtores de cana e 308 unidades de processamento industrial, todas privadas, produzindo 17,7 milhões de toneladas de açúcar e 13,7 milhões de $\mathrm{m}^{3}$ etanol pôr ano.

A indústria da cana-de-açúcar no Brasil mantém o maior sistema de produção de energia comercial da biomassa, no mundo, através do etanol (substituindo cerca de $20 \%$ da gasolina) e do uso quase total do bagaço (equivalente a 11 milhões toneladas de óleo), e na produção de plásticos biodegradáveis, açúcares não calóricos e compostos químicos de interesse farmacêutico.

A agroindústria canavieira é responsável por milhões de empregos, o que evidencia a importância social da cultura (Sgrillo, 1979), com a geração de 
divisas através da exportação de açúcar e álcool e pelo aproveitamento racional da biomassa vegetal, gerando energia elétrica e produtos para a indústria alcoolquímica e para a alimentação de animal entre outros (Raizer, 1998).

Com tecnologias comerciais, e usando somente o bagaço, é possível gerar excedentes de cerca de 3 quilowatts de energia elétrica. A utilização de parte da palha e de ciclos mais eficientes poderia elevar este potencial para 5 quilowatts aumentando ainda mais a importância econômica da cana-de-açúcar.

No município de Piracicaba, a cultura da cana-de-açúcar representa $35 \%$ da área territorial (47.000 hectares), gerando 6.100 do total de 7.150 empregos rurais (85\%), segundo a União da Agroindústria Canavieira do Estado de São Paulo (Fernandes,1999)

$\mathrm{Na}$ Copersucar, o faturamento bruto anual é de $\mathrm{R} \$ 3,7$ bilhões (safra 2001/2002). As usinas e destilarias associadas a Copersucar processam anualmente um volume aproximado de 60 milhões de toneladas de cana e realizam uma produção da ordem de 3,6 milhões de toneladas de açúcar e 2,4 bilhões de litros de álcool (safra 2001/2002). Esses volumes permitem à cooperativa uma participação de, aproximadamente, $21 \%$ do mercado brasileiro de açúcar e de álcool.

A cana-de-açúcar obteve um grande sucesso de produção através da utilização de variedades advindas do melhoramento genético clássico desenvolvido pelos centros de pesquisas e estações experimentais como Instituto Agronômico de Campinas e a Copersucar. A cana-de-açúcar atualmente cultivada é originária de um cruzamento entre Saccharum officinarum e Saccharum spontaneous o que aumentou a produtividade e a resistência a doenças dos clones cultivados. O mapeamento genético dos cultivares mais utilizados está sendo realizado (Grivet e Arruda, 2001), porém a seleção de variedades mais produtivas, resistentes a pragas e doenças e adaptadas a ambientes diversos por intercruzamentos, é um processo demorado, que leva de 12 a 15 anos. 
Hoje o seqüenciamento do genoma de várias plantas tem facilitado e acelerado a identificação de genes responsáveis por qualidades desejáveis, possibilitando a manipulação subseqüente de genes de interesse através de técnicas de genética molecular. Isso aumentou a eficiência e obtenção de variedades bem sucedidas, produzindo-se plantas resistentes a múltiplas doenças e mais adaptadas e produtivas, o que diminuiu drasticamente as perdas na agricultura, além de permitir o aproveitamento de solos até então não utilizáveis.

Inúmeros centros no Brasil se dedicaram a estudar a cultura, tentandose adquirir variedades mais produtivas e resistentes a doenças, uma vez que os fungos conseguem se "adaptar" æ̀ variedades resistentes, tornando-as susceptíveis. A obtenção de plantas transgênicas resistentes à praga e patógenos ainda é um grande desafio para a comunidade científica em todo o mundo. Desde a liberação comercial da primeira cultura transgênica, em 1996 (algodão transgênico resistente ao Bacillus thuringiensis (Bt)), questionou-se o aparecimento de quebra de resistência. Entretanto, através do uso de estratégias cuidadosas de cultivo, tais como, o cultivo combinado de culturas resistentes e não resistentes no campo, pôde-se prolongar a durabilidade da resistência dessas plantas engenheiradas (Dempsey et al., 1998).

O objetivo principal da biotecnologia, para o desenvolvimento de plantas resistentes a patógenos e pragas, é disponibilizar comercialmente culturas de importância econômica que, por apresentarem graves problemas fitossanitários, comprometem sua alta produção ou a sanidade do meio ambiente (com utilização de agrotóxico). Isto somente foi possível através do isolamento de novos genes relacionados aos mais variados mecanismos de defesa em plantas e à transformação genética. Por isso, programas de melhoramento genético que visam basicamente a desenvolver plantas resistentes só podem ser eficientes se empregarem um promotor específico (que somente expresse no local da resposta). Assim sendo, tem-se uma estratégia que é a de selecionar promotores ativos somente no local de infecção. Genes 
que codificam para proteína de defesa são controlados por promotores sítioespecíficos e ampliam a possibilidade de obtenção de plantas resistentes, como no presente caso de plantas susceptíveis àferrugem.

\subsection{Doenças da cana-de-açúcar}

Existem diversos fatores que reduzem a produtividade da cana-de- açúcar entre eles os fatores fitossanitários que têm sido a grande preocupação para os produtores.

Em culturas de cana-de-açúcar foram descritas mais de 216 doenças, das quais 38 foram encontradas no Brasil, dentre as quais 10 de maior importância econômica para os produtores. Para o melhoramento da cana, as principais medidas de controle são: variedades resistentes, viveiros sadios, tratamento térmico, escolha do local e época de plantio e manejo e época de colheita. Com o mecanismo de resistência selecionado na cana-de-açúcar, quase todas as variedades são capazes de conviver com o causador da doença e tolerar a sua presença sem apresentar perda econômica. Isso faz com que encontremos a doença em condição extremamente favorável, mas os sintomas desaparecem com o crescimento da planta ("escaldadura das folhas", 0 "raquitismo das soqueiras" e podridão das raízes). A ocorrência desse fato pode causar perdas não observadas pelos produtores, contudo as doenças transmitidas internamente pelas mudas como o "mosaico" e o "carvão", são controlados com variedades resistentes ou tolerantes a seus agentes.

Entretanto as doenças causadas pelos fungos, como a "estria vermelha", a "ferrugem da cana", "mancha ocular" e "mancha amarela", são relativamente fáceis de se identificar porque produzem sintomas evidentes nas folhas, uma vez que estão sempre associadas às condições favoráveis do clima 
e, como essas doenças não colonizam toda a folha, é mais difícil de ocorrer a transmissão pela muda. (Encarte de informações agronômicas- № 67Setembro/94).

\subsection{Ferrugem - Fungo: Puccinia melanocephala}

A ferrugem da cana foi encontrada no Brasil em1986, tendo aparecido pela primeira vez no Município de Capivari, São Paulo. Posteriormente, a doença foi descoberta em Piracicaba e muitos outros municípios.

Conforme Sordi et al., (1986) e Sanguino et al., (1987), a doença foi relatada pela primeira vez no sul e no sudeste do Brasil e, logo no ano posterior, em Pernambuco e Alagoas (Cruz, 1992).

Em Pernambuco, a variedade B43-62, cultivada na região, foi a mais atingida na época, tendo em vista a alta susceptibilidade. Em Alagoas, algumas variedades de comportamento desconhecido apresentaram reações intermediárias e de susceptibilidade, a exemplo da RB721012, que naquela ocasião vinha em crescente expansão e gradativamente deixou de ser cultivada.

Esse fato contribuiu para que ocorresse um processo de substituição varietal, através do cultivo de materiais genéticos resistentes à ferrugem; entretanto, muitas dessas variedades intermediárias e susceptíveis continuam sendo cultivadas, haja vista as dificuldades para a obtenção, em curto espaço de tempo, de genótipos resistentes e que tenham a características de alta produtividade de açúcar por hectare.

Conforme Matsuoka (1993), a ocorrência da doença é mais danosa à cana-de-açúcar nos locais de temperatura não muita elevadas e nas épocas de maior umidade do ar, observando-se ainda ser a cana-de-açúcar mais susceptível na primeira metade de seu ciclo vegetativo, mais especificamente 
dos dois aos oito meses de idade, existindo variedades que são resistentes à doença na fase adulta e susceptíveis na sua fase jovem, enquanto outras sofrem ataques em todo o ciclo, desde que as condições climáticas sejam favoráveis ao patógeno.

O surgimento da doença e o seu desenvolvimento estão relacionados com a interação Genótipo X Agente Patogênico X Ambiente. As plantas susceptíveis apresentam manchas cujos sintomas têm início com pequenas manchas amareladas, geralmente circulares ou elípticas e recobertas pela cutícula da planta. Com o desenvolvimento da doença, essas manchas aumentam de tamanho e rompem a cutícula, expondo a massa de uredósperos produzida pelo patógenos (Figura 1).

Nesse estágio, as manchas são denominadas pústulas. Na parte inferior das folhas, são amareladas a marrom escuro, mostram formação de esporos subepidêrmicos com ruptura da epiderme para a sua liberação (Prancha 196). Em variedades muito susceptíveis, as pústulas agrupam-se, formando placas de tecidos necrosados. Plantas muito atacadas têm 0 crescimento retardado, com folhas queimadas e sem brilho, e também o processo fotossintético é afetado tanto pela retirada de nutrientes, como pela queda da folha provocada pelo patógeno. 


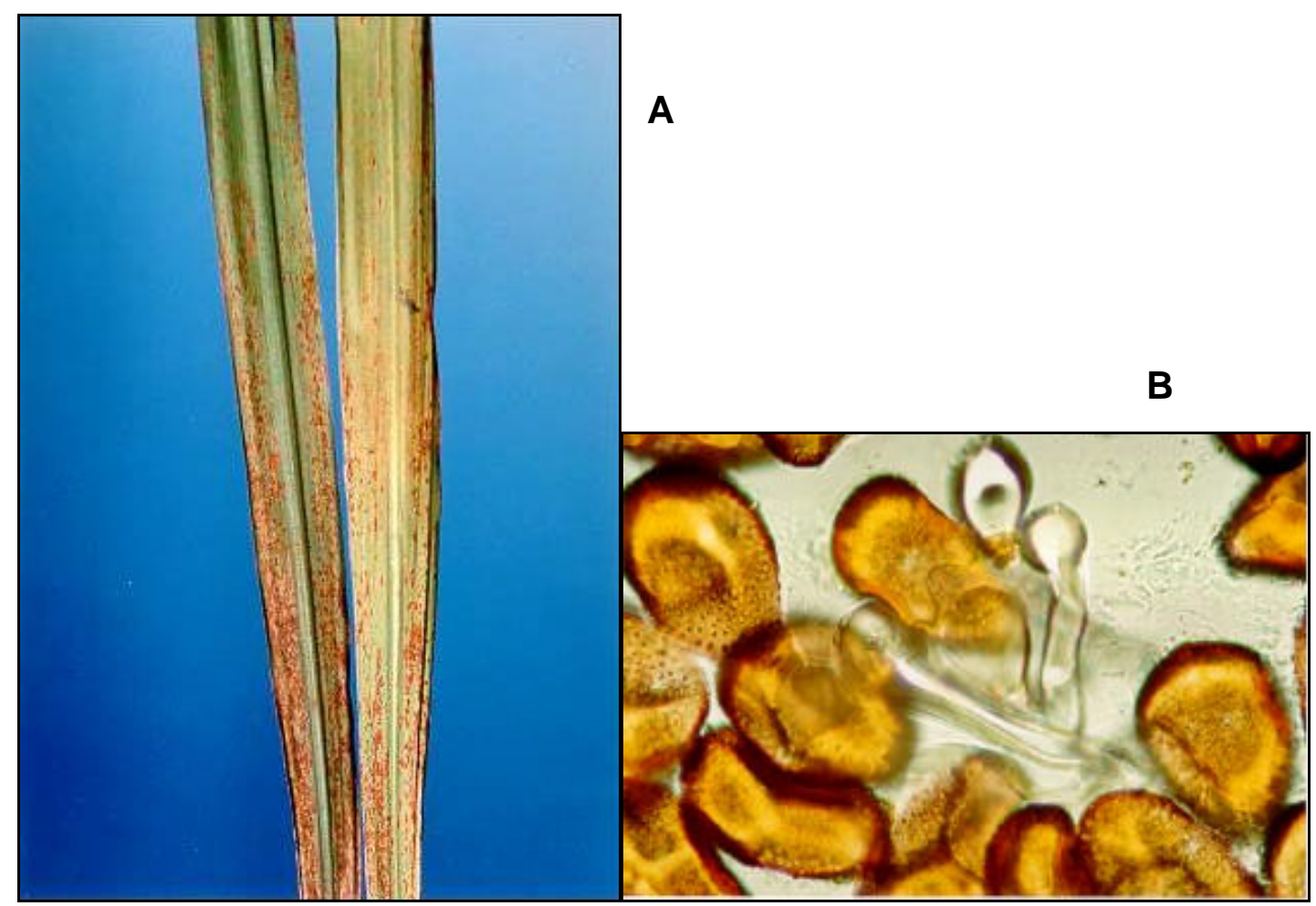

Figura 1 - (A) Cana-de-açúcar infectada com o fungo (ferrugem) Puccinia melonocephala - (B) Processo de esporulação do fungo em tamanho (20x)

\subsubsection{Interação Planta X Patógeno}

Os vegetais sofrem constantes agressões por agentes abióticos e bióticos tais como vírus, bactérias, fungos, insetos. A indução de resistência em plantas a patógenos é conhecida há mais de 50 anos,(Chester, 1933; Gaümann, 1946; Muller \& Borges, 1940). Muito tempo depois, o fenômeno começou a ser investigado de forma mais direcionada, visando-se a aumentar a produtividade das culturas pelo controle das enfermidades das plantas. 
Agrios,(1997); Romeiro,(1985); Romeiro,(1987) e Tomiyama,(1963) assumiram que em fitopatologia a imunidade é uma regra e a susceptibilidade é exceção. Se assim não fosse, qualquer patógeno seria capaz de infectar qualquer planta e em curto prazo evolutivo, os vegetais desapareceriam da face da terra.

Em plantas, a resistência natural a microrganismos patogênicos é um mecanismo de defesa já existente, independente da chegada do inóculo ao sítio de infecção. Essas defesas pré-existentes são denominadas de constitutivas (Goto, 1990; Kiraly et al., 1970; Sticher et al., 1997). Em contraposição, plantas possuem outros mecanismos de defesa ainda mais eficientes que permanecem inativos ou latentes, só sendo acionados ou ativados, quando os mesmos entrarem em contato com os agentes de indução. Neste caso, a resistência é dita dinâmica, pós-infeccional ou induzida (Agrios, 1997; Colson \& Deverall, 1996; Fodor et al., 1998; Kiraly et al., 1970; Sticher., 1997).

A interação entre a planta e o patógeno pode ser compatível (o patógeno invade o tecido vegetal, multiplica-se e provoca a doença na planta) e incompatível (o patógeno, ao penetrar no tecido vegetal, encontra as defesas da planta). A diferença entre as duas está relacionada com a presença ou ausência de um gene de resistência na planta e de um gene de avirulência no patógeno. Na interação incompatível, é fundamental a ação recíproca gene a gene entre a planta e o patógeno (Flor, 1947), para que ocorra a ativação rápida do mecanismo de defesa da planta, sendo este específico, o que significa dizer que uma mesma planta pode reconhecer um determinado patógeno A e não reconhecer o patógeno B (Grant et al, 1995).

O patógeno virulento não possui o gene avr, cujo produto gênico é reconhecido por uma proteína de resistência da planta, em que o patógeno se esquiva da ativação rápida do mecanismo de defesa, podendo se multiplicar e produzir a doença. Já o patógeno avirulento possui o gene avr, um indutor direto e específico, que vai interagir com o produto do gene de resistência (proteína $R$ ), podendo por ele ser modificado. O produto desta modificação 
(indutor indireto) é que irá interagir com a proteína de resistência. $O$ mecanismo de indução e amplificação da resposta de defesa em plantas é chamado de eliciação. As moléculas que induzem ou amplificam são chamadas de eliciadoras, e podem ser de origem protéica, lipídicas ou polissacarídica (Anderson, 1988). Atualmente o estudo dessa molécula tem sido usado como uma das ferramentas para aumentar a resistência em plantas (Mourgues et al, 1998).

A ativação do gene é o processo que ocorre após a transdução de sinal. Esse gene pode ser ativado tardiamente e estar relacionado ao mecanismo de defesa, resultando na produção de lignina e calose (Ride et al, 1983.; Collinge et al, 1993), que são depositados na parede celular fortalecendo-a e evitando a penetração de outros patógenos. Enzimas hidrolíticas como quitanases e glucanases, também são produtos dos genes avr e são originadas em resposta a ataques do patógeno (Bowles, 1990; Paulot et al, 1993; Collinge et al, 1993), que neutralizam peptídeos patogênicos ativos e inibem a síntese de proteínas relacionadas àinfecção pelo patógeno $(P R)$.

A $H R$ (resposta de hipersensibilidade) é uma reação rápida, induzida no vegetal no qual ocorre a morte celular localizada na área de infecção do patógeno avirulento. Desta maneira, acredita-se que a planta impede a multiplicação do patógeno nas células infectadas, limitando e interrompendo o processo de disseminação da infecção. O fenômeno observado após a transdução de sinal e a ativação local de genes relacionados com a defesa vegetal é denominado de resistência sistêmica adquirida $(S A R)$. Esta resposta consiste na produção de um estado de imunização temporária da planta a uma infecção patogênica. Estes genes constituem uma família gênica, que codificam para as proteínas $\beta$ 1-3 glucanases as quitinases em suas formas ácidas e básicas e as peroxidases. Também o ácido salicílico $(S A)$, o etileno e o ácido jasmônico têm ação sinergística na expressão de genes PR por eliciação (Xu et al, 1994) e todos estão relacionados àativação de defesas das plantas. 


\subsubsection{A cana-de-açúcar e a era genômica}

Com a era genômica, as manipulações genéticas serão dirigidas, aumentando a eficiência e a obtenção de variedades bem sucedidas, adaptadas e produtivas, o que deve diminuir drasticamente as perdas na agricultura. Com isso, a cultura da cana-de-açúcar ingressando na era genômica, tem apresentado um grande trunfo ao revelar um banco de dados representados por 250.000 ESTs (Expressed Sequence Tags ou Etiquetas de Seqüências Expressas), seqüências de DNA que representam trechos de mRNA mensageiros posteriormente traduzidos em proteínas. Esses genes são expressos em diferentes órgãos, como folha, raiz, colmo, flores e sementes (Vettore et al., 2001) e muitos estão envolvidos em vias de transdução de sinal. Durante o seu ciclo de vida, as plantas são constantemente bombardeadas por sinais ambientais e uma resposta adequada a cada um desses sinais é determinante para a sua sobrevivência e para a produção máxima. Essas respostas podem ser fisiológicas, bioquímicas, morfológicas ou de desenvolvimento, que estão sendo hoje o foco de recentes estudos sobre transdução de sinal.

As investigações dos mecanismos de integração de todos os sinais levaram à identificação de vários hormônios que agem na planta de uma maneira tanto local quanto sistêmica, alterando o padrão de expressão de genes responsáveis por efetuar mudanças necessárias à resposta de sinais ambientais. Em muitos casos, o melhoramento genético de uma planta implica a manipulação de componentes que mediam a transdução de sinais, explorando as redes de comunicação que detectam alterações do meio ambiente e que podem desencadear mudanças na expressão gênica. A partir da análise de genomas completos que foram seqüenciados, como 0 da levedura Saccharomyces cerevisae, da mosca da fruta Drosophila melanogaster, do verme Caenorhabditis elegans e da Arabidopsis thaliana, foi estimado que $7 \%$ a 
$15 \%$ de genes de um organismo codificam para proteínas envolvidas na transdução de sinal (Souza et al., 2001), e que 900 ESTs já foram relacionados com diferentes vias de transdução de sinal em cana-de-açúcar. Essas proteínas estão relacionadas ao complexo sistema de sinalização que as plantas desenvolveram ao longo da sua evolução o que permite a adaptação à vasta gama de condições ambientais através da sinalização de hormônios (Trewavas, 2001). Através de técnicas de genética molecular, muitas das enzimas de síntese e degradação de hormônios foram associados a processos de crescimento, envelhecimento, desenvolvimento, diferenciação, amadurecimento, dormência e resposta a ferimentos e defesa contra doenças. Estão relacionados entre os hormônios vegetais o gás etileno, as giberelinas, o ácido jasmônico, o ácido abscíssico e as auxinas e citocininas e são estas enzimas que participam na biossíntese desses hormônios que estão representadas nos conjuntos de ESTs da cana-de-açúcar.

A integração dos sinais ambientais durante as várias fases do ciclo de vida da planta pode se dar pela ação coordenada e simultânea de vários hormônios, que alteram, em muitos casos, a síntese de outro. A obtenção de plantas transgênicas alteradas nas vias de síntese de hormônios é de interesse econômico e tem sido alvo de intensa pesquisa, uma vez que esses sinais ambientais podem ser por ferimentos, peptídeos, produtos derivados de microorganismos e patógenos, além de outros agentes do meio ambiente, como luz, gravidade, temperatura, vento, água, nutrientes e minerais do solo. Os sinais extracelulares são percebidos por receptores que ficam na membrana celular e que podem ser de diversos tipos, entre eles as proteínas $\mathrm{G}$ (ligadas a canais de íons) e aqueles que possuem atividades enzimáticas, como as quinases (enzimas responsáveis pela fosforilação de resíduos de aminoácidos no substrato protéico). Esta classe de receptores constitui a base molecular do reconhecimento do patógeno pelo gene $\mathrm{R}$ de resistência àdoença.

As informações recebidas pelos receptores extracelulares são transmitidas para alvos intracelulares através dos chamados mensageiros 
secundários, que, em geral são moléculas difusíveis. Mensageiros secundários da família do fosfatidilinositol estão presentes em cana-de-açúcar, uma vez que os ESTs que codificam as enzimas da via de síntese dessas moléculas foram detectadas, e os ESTs estão relacionados com o metabolismo do íon cálcio, como canais de cálcio, calmodulina, calreticulina e calnexina, que são mensageiros secundários importantes e ativos na transmissão de sinais em cana-de-açúcar, por isso mudanças nos níveis de cálcio mediadas por canais de cálcio estão relacionadas com o início de algumas respostas, como o fechamento de estômatos, re-orientação do crescimento do tubo do pólen e aumento da espessura da parede em resposta ao vento e também ao ataque de patógenos.

A transdução de sinal ocorre em uma cascata de eventos de fosforilação e desfosforilação de proteínas catalisadas pelas proteínas quinases e proteínas fosfatases. A ativação dessas enzimas faz-se mediante respostas a estímulos distintos, como luz, agressão por patógenos, reguladores de crescimento, estresses variados e deprivação de nutrientes que são percebidos por receptores. No caso da fosforilação em cascata presente na cana-de-açúcar, destaca-se a via do AMPquinase, que é uma das mais conhecidas em plantas e representa um exemplo clássico de cascata de fosforilação. O módulo básico da cascata é constituído de três quinases chamadas MAPk, MAPKK ou (MEK) e MAPKKK (ou MEKK). Ao menos oito MAPKs foram identificadas entre os clusters de ESTs da cana-de-açúcar. Está postulado que sinais extracelulares, como os indicados na Figura 2, são captados por receptores, na sua maioria ainda desconhecidos, levando à ativação da MAPKKK, que fosforila a MAPKK que,por sua vez, fosforila a MAPK. Está ultima proteína quinase provoca ativação da transcrição de genes de defesa e proteção a estresses, por exemplo. Além da ativação verificada diretamente sobre a atividade de proteína quinase dessas enzimas, certificou-se que os genes que as codificam têm a transcrição ativada em resposta a vários sinais de patógenos, conferindo resistência sistêmica a doenças. 
A engenharia genética da cana-de-açúcar e de outras gramíneas tem, portanto, um futuro garantido e promissor. As informações derivadas das análises de 250.000 ESTs da cana-de-açúcar, somadas aos dados de sequenciamento de ESTs de genoma como do arroz e do milho, compõem uma base sólida para a elucidação dos mecanismos de defesa, de adaptação dos solos e de crescimento dessas plantas em regiões de cultivos diferenciados. (Sucast: http:// sucest.lad.ic.unicamp.br). 


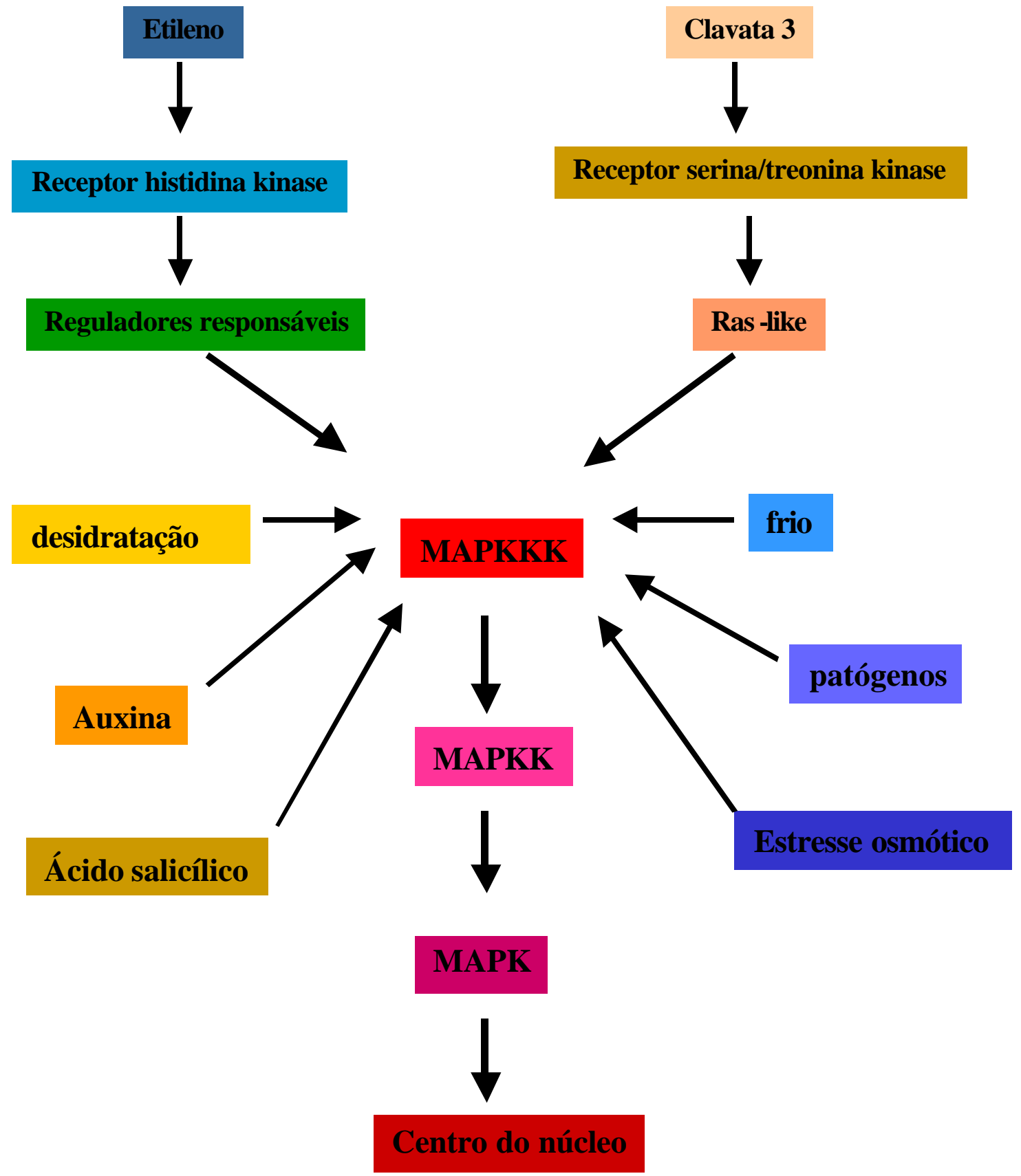

Figura 2 - Modelo de elicitores externos e resposta de estimulação em cascata de quinases 


\subsection{Transformação genética}

Utilizando as técnicas de cultura de tecidos vegetais e da engenharia genética, ampliaram-se consideravelmente as possibilidades da introdução de genes de interesse agronômico, inclusive para o controle de fitopatógenos (Dominguez et al., 2000). A introdução de gene exógenos em plantas pode ser feita através da Agrobacterium tumefaciens ou por métodos diretos como a eletroporação e a biolística.

A Agrobacterium tumefaciens é uma bactéria de solo do tipo bacilo gran negativo (Smith \& Townsend. 1907), causadora da doença conhecida como "galha da coroa" ("Crow gall"), em que ocorre um processo de transferência natural de genes entre a agrobactéria e a célula vegetal, quando fragmentos de DNA bacteriano (T-DNA) são transferidos para dentro da célula vegetal , integrando-se ao genoma nuclear (Ream \& Gelvin, 1996). As duas regiões que estão envolvidas na transferência de genes são o T-DNA e a região vir. Com a utilização da Agrobacterium tunefaciens, como vetor de transformação, partes do T-DNA são deletados e substituídos por genes de interesse. Assim, a linhagem desarmada retém a capacidade de transformação e não forma tumores nas plantas hospedeiras. Explantes inoculados com as linhagens desarmadas têm a capacidade regenerativa e grande porcentagem de produção de plantas transgênicas (Brasileiro, 1998).

Arenciba et al (1998) publicaram os primeiros relatos de transformação em cana-de-açúcar empregando Agrobacterium tumefasciens. Os autores determinaram que fatores como o uso de calos jovens, a cultura de células e a preindução de organogênese ou embriogênese levaram ao sucesso do método. Os genes exógenos introduzidos via Agrobacterium se mantêm de forma estável, segregando na progênie, de acordo com as leis de Mendel.

O processo de eletroporação consiste na indução temporária de poros nas membranas celulares de protoplastos, produzidos por um campo elétrico, 
permitindo, assim, a passagem de íons e moléculas, entre elas, DNA contendo os transgenes. O método não é muito empregado para monocotiledôneas devido æ̀s dificuldades encontradas para a transformação destas (Birch 1997).

A maioria dos aparelhos de eletroporação emprega pulsos de alta voltagem que necessitam ser otimizados para cada cultura. A técnica, entretanto, possui limitações em muitas espécies que têm dificuldade para a produção de protoplastos. Também a regeneração de células e tecidos, a partir de protoplastos transformados, tem encontrado dificuldades em muitas culturas, principalmente em cana de açúcar.

A biolística é o procedimento que utiliza o bombardeamento com microprojéteis objetivando a inserção de DNA exógeno no genoma das plantas. Para o seu uso, segundo Moore (1996) deve-se ter em mente uma série de processos pré-determinados para a adequação da técnica. Tendo em vista isto, o primeiro passo consiste na escolha do tecido alvo que receberá os transgenes; em seguida, deve-se escolher o gene-repórter o qual indicará que tipo de inserção será obtido. Junto a este, temos um gene marcador seletivo e um meio seletivo, para que sejam colocadas em evidência somente as células transformadas.

Por último, temos a escolha do gene que codificará alguma característica agronômica de interesse e o promotor que se responsabilizará por dirigir a expressão de cada gene.

Gambley et al. (1993) verificaram que a escolha do alvo é um dos fatores fundamentais neste processo. Dentre todos os testes em cana, observaram que os calos embriogênicos foram os melhores, apesar de possuírem uma alta probabilidade de variação somaclonal quando comparados com os tecidos meristemáticos. Além disso, o uso dos calos embriogênicos possui uma certa vantagem pois regeneram plantas com grande facilidade.

Segundo Birch et al. (1995) o uso de calo ainda confere a vantagem de fácil manuseio no processo de seleção em meio de cultura, além de se obter alta produção de material para o uso em bombardeamento num pequeno espaço de 
tempo, resultando também na diminuição do aparecimento de quimerismo, muito comum quando se utilizam alvos mais organizados.

Taylor et al. (1992) e Birch et al. (1995) realizaram vários experimentos com diferentes variedades de cana de açúcar, constatando que estas diferiam na facilidade para a produção de calos embriogênicos. Observaram que uma das variedades era incapaz de produzir calos em quantidade suficiente para que fosse feito o bombardeamento. Em outras variedades, verificaram que um período de 10 a 12 semanas seria suficiente para garantir uma produção razoável de calos para se fazer o bombardeamento adequadamente.

Vain et al. (1993) e Birch et al. (1995) observaram que o uso de manitol e sorbitol, após o bombardeamento, poderiam reduzir as injúrias celulares. Seu uso seria, no mínimo, entre 4 horas antes ou 4 horas após o bombardeamento.

As condições de bombardeamento têm sido alvo de vários estudos e análises. Os pesquisadores procuram um mecanismo universal que possa transportar substâncias tais como anticorpos, enzimas e materiais genéticos para o interior das células. Isso provocou um intenso aprimoramento desta técnica através dos anos, sendo que a mesma foi modificada sucessivamente ano após ano por pesquisadores de diversas partes do mundo (Sanforr et al., 1987; Klein et al., 1988; Birch \& Franks, 1991).

Segundo Finer et al. (1995) o aparato biolístico pode ser facilmente reproduzido uma vez que utiliza vácuo parcial e gás hélio. Possui um porta filtro de seringa acoplada a esta saída de gás, responsável pelo carregamento das micropartículas. Este tipo de equipamento foi o recomendado por Birch et al. (1995) para ser utilizado em variedades de cana.

A otimização das condições de bombardeamento implica um aumento na freqüência de transformações estáveis, tendo também, segundo Birch et al. (1995), um aumento de aproximadamente dez vezes na eficiência da transferência dos genes.

Existem pelo menos cinco fatores que interagem entre si, afetando a freqüência da expressão transiente das células e tecidos bombardeados, sendo 
eles: o tamanho e a composição dos microprojéteis, a impregnação das partículas com o DNA, a velocidade do microprojétil durante o impacto, o grau de danos provocados pelo bombardeamento e, por último, a constituição genética bem como o tipo de tecido. Estes fatores determinam o grau de otimização bem como os parâmetros que serão utilizados no bombardeamento (Birch \& Franks, 1991).

Russel et al. (1992) observaram que os danos provocados pelo bombardeamento podiam ser minimizados quando as condições eram otimizadas através de um ajuste da pressão de disparo bem como pela distância do alvo e a escolha do microprojétil ideal.

Vários autores relatam que o surgimento de uma alta variação somaclonal é uma característica comum dos equipamentos de transferência dos genes através dos microprojéteis, quando culturas (tratamentos), aparentemente idênticas, são bombardeadas sucessivamente (Birch \& Franks, 1991; Klein et al., 1988; Sanford, 1987).

Birch et al. (1995) relatam ainda que no bombardeamento dos calos embriogênicos da cana, normalmente se obtém uma produção de 160-260 células positivas $/ \mathrm{cm}^{2}$ durante os ensaios de expressão GUS. Também Falco (1998) conseguiu a produção de plantas de cana de açúcar transformadas para o gene neo, que confere resistência a canamicina e geneticina, e para o gene bar, que confere resistência ao herbicida glufosinato de amônio, empregando o bombardeamento de micropartículas em calos .

\subsubsection{Transformação da cana-de-açúcar}

As primeiras canas transformadas foram relatadas por Bower \& Birch (1992), da Austrália, obtidas através do bombardeamento. Foram plantas transformadas com o gene neo que codifica a enzima neomicina 
fosfotransferase II, que confere resistência a antibiótico aminoglicosídeos, como a geneticina e canamicina e uid $-A$ que codifica a beta-glucuronidase, permitindo a visualização do sucesso da transformação ou expressão transiente.

Chowdhury \& Vasil (1992) bombardearam calos de variedade híbrida com o gene bar, e constataram que não houve regeneração das plantas, isto por causa da idade avançada dos calos utilizados.

A otimização das condições de bombardeamento tem demonstrado uma alta eficiência de co-transformação em cana, usando dois genes. Birch (1996) citou o bombardeamento como sendo um sistema bastante eficiente para a inserção de genes de variedades de cana-de-açúcar e ressaltou a importância dos produtos atingirem uma maior competitividade no mercado. Falco et al. (2000) utilizou bombardeamento de partículas para co-transformar duas variedades comerciais brasileiras com genes de resistências a antibióticos e ao glufosinato de amônio.

As técnicas de transformação de cana-de-açúcar estão sendo amplamente estudadas e atualmente existem plantas transgênicas para as mais variadas características. Entretanto os métodos apresentam problemas quanto à complexidade de integração do transgene, pois um grande número de cópias do gene é inserido em regiões nas quais não ocorre uma transcrição ativa. Assim é importante citar que alguns pesquisadores ( Arencibia et al., 1998; Elliot et al., 1998) têm estudado a aplicação da transformação de cana-de-açúcar mediada por Agrobacterium tumefaciens, técnica que promove a inserção de poucas cópias em sítios altamente expressos do genoma.

As perspectivas de transformação genética de cana-de-açúcar foram incrementadas pelo projeto genoma da cana, financiado pela FAPESP e Copersucar. Este projeto identificou milhares de seqüências expressas . 


\subsubsection{A escolha do alvo}

Vários tipos de materiais podem servir como alvo no processo de biolística. Folhas, calos, raízes, células em suspensão e outros explantes têm sido empregados em inúmeros trabalhos. A transformação de meristemas apicais tem a vantagem de evitar a ocorrência de variação somaclonal, decorrentes da cultura de calos, entretanto podem surgir quimeras no processo.

\subsubsection{Seleção dos transformantes}

Um dos genes mais empregados como marcador de transformação é o gene gus ( $\beta$ glucuronidade) (Jefferson et al.,1987). A enzima produzida pelo gene é uma hidrolase, que converte o substrato 5 bromo 4 cloro 3 indolil $\beta D$ glucuronideo (X gluc) em um produto azul escuro insolúvel. A expressão do gene gus pode ser acompanhada histoquímica, fluorimetrica e enzimaticamente. Quando se usa o 4 metilumbeliferil $\beta$ D glucuronídeo como substrato, forma-se o 4 metil umbeliferona que é fluorescente em pH alcalino (Jefferson et al.,1987).

O sucesso de um determinado marcador de seleção depende das características do agente de seleção (gene de resistência) e do material vegetal (Angenon et al., 1994). O agente de seleção deverá inibir completamente o crescimento das células não-transformadas. No entanto, o efeito da morte dessas células não deverá influenciar no crescimento das células transformadas, que são resistentes ao agente de seleção.

O gene marcador de seleção mais utilizado em transformação genética de planta é o gene nptll ou neo que codifica a neomicina fosfotransferase II (NPTII (EC 2.7.1.95)). O gene nptll é utilizado como marcador de seleção em diversas espécies vegetais, pertencentes a diferentes famílias (Ritchie \& Hodges, 1993). 
A enzima NPT II atua transferindo o grupamento $\gamma$ fosfato do ATP para um grupo 3hidroxil da porção amino-hexose dos antibióticos aminoglicosilados, como a canamicina, a neomicina, a geneticina (G418) e a paromomicina, que são assim detoxificados por fosforilação (Benveniste \& Davies, 1973). Quando ativos, esses antibióticos inibem a síntese de proteínas nas células procarióticas, ligando-se às subunidades 30s e 50s dos ribossomos e impedindo a iniciação da tradução (Davis, 1988). Na célula vegetal, esses antibióticos interferem da mesma maneira na síntese protéica em mitocôndrias e cloroplastos, que possuem ribossomos semelhantes aos das bactérias, resultando na clorose e inibição do crescimento do tecido vegetal (Weide et al., 1989).

Também a proteína verde fluorescente (GFP) de Aequorea victoria começou a ser usado como uma proteína repórter em plantas. É particularmente útil o uso da fluorescência da GFP, pois pode ser usada de maneira não destrutiva, considerando-se que o uso de genes-repórteres, baseados na atividade de enzimas, requer freqüentemente destruição do tecido de planta. $O$ uso de GFP, como um repórter, habilita tecidos de plantas transgênicas serem determinadas in vivo em qualquer fase de crescimento. A quantificação de GFP em extratos de plantas transgênicas aumentou a utilização de GFP como uma proteína de repórter. A quantificação de uma variante da GFP, a mGFP5-ER em extratos de folha de tabaco por excitação de UV e uma sGFP (S65T), variante em folhas de cana-de-açúcar e calos, pode ser determinada por excitação de luz azul que usa o Sistema BioRad VersaFluor ${ }^{\wedge T M}$ Fluorometer ou o Labsystems Fluoroskan por ascensão, equipada com um filtro de emissão na faixa (510 \pm $5 \mathrm{~nm})$.

Atualmente a microscopia por fluorescência tem uma função essencial na área da biologia molecular, pois permite a visualização de componentes celulares específicos. Assim, a descoberta da GFP tem revolucionado o campo da análise experimental. A luminescência é produzida quando a energia emitida pela luz U.V. é transferida para o elemento cálcio, ativando a fotoproteína aequorina para proteína verde fluorescente. (Sullivan \& Kay, 1999). A clonagem 
do gene GFP e sua subseqüente expressão em sistemas heterólogos surgiram como um novo modelo de gene repórter. A proteína GFP pode ser expressa tanto em organismos eucarióticos quanto em procarióticos e não necessita de qualquer cofator ou substrato. Muitas variações são encontradas do cromóforo GFP. Vários laboratórios têm trabalhado na busca do desenvolvimento de proteínas derivadas da GFP que possam servir também como genes-repórteres. Da mutação de quatro aminoácidos (Ser 65 para Gly; Val 68 para Leu; Ser 72 para Ala e Thr 203 para Tyr), surgiu a proteína EYFP, a qual emite uma coloração amarela (Enhanced Yellow Fluorescent Protein). AEYFP é muito útil tanto no monitoramento da expressão de genes de interesse nos diversos tipos de tecidos celulares quanto na rápida identificação dos tecidos transformados.

\subsubsection{Escolha do promotor}

Uma das seqüências reguladoras mais utilizada na transformação genética mediada pela Agrobacterium tem sido o promotor 35s, isolado do vírus do mosaico da couve-flor (CaMV) (Guri e Sink et al., 1988; Chang e Chan, 1991; Urbano et al., 1994). Este promotor tem sido bastante empregado como um componente de genes quiméricos, com expressão constitutiva em plantas transgênicas. $O$ promotor $35 \mathrm{~s}$ é muito ativo, funcionado em uma ampla variedade de células e tecidos de mono e dicotiledôneas.

Diversos autores têm questionado a utilização de promotores constitutivos dirigindo a expressão de genes exógenos na planta, considerando que sua expressão constitutiva pode interferir no estado fisiológico da planta (Samac Xá, 1991; Oommen et al., 1994).

Em monocotiledôneas, o gene promotor mais utilizado tem sido o da ubiquitina do milho (Ubi-1) e da actina de arroz (act1). 


\subsubsection{Escolha do transgene}

Inúmeros trabalhos têm sido desenvolvidos em relação à transformação de plantas, empregando transgenes na tolerância a herbicidas (Falco, 1998), o gene da capa protéica do mosaico da cana de açúcar (Smith et al., 1992), o gene bt para resistência a pragas (Moore, 1996). Também o gene da lactoferrina, uma glicoproteína que possui propriedade antibacteriana, foi inserido em tabaco, causando uma diminuição dos sintomas causados por $R$. solanaceum. Em tabaco, outra proteína, a ttr (tabtoxina) foi expressa em plantas transformadas, levando a uma completa resistência da planta a $P$. syringae.

No presente projeto, foi escolhido o gene PR5K, (Wang et al., 1996) por pertencer ao grupo das $P R$ proteínas, um receptor de membrana relacionado à resistência das plantas a doenças fúngicas. O domínio da PR5K está relacionada ao grupo das PR5 proteínas, que se acumulam na presença de patógenos.

\subsubsection{Análises moleculares do material transformante}

Após os eventos de biobalística, o DNA exógeno introduzido via micropartículas poderá ou não estar integrado ao genoma da planta. Após inúmeras divisões celulares, a permanência do elemento marcador de seleção caracterizará um evento de transformação positiva. Caso contrário, o tecido que foi submetido ao processo de bombardeamento ao passar pelo processo de seleção química, por exemplo resistência a antibióticos, herbicida etc., não será viável, vindo a perecer no processo de multiplicação. Entretanto, a simples passagem pelo processo de seleção não é indicador de transgenicidade, termo que se refere àcélula que teve o DNA exógeno integrado ao genoma. Análises 
bioquímicas e moleculares de tecidos transformados se tornam necessárias para se avaliar se o material é transgênico ou não. Também é necessário se avaliar o material quanto ao numero de copias dos transgenes que serão inseridas na célula/tecido transformadas (Register, 1997).

A técnica empregando a metodologia da transcriptase reversa ou PCR é uma das mais empregadas para a confirmação da presença ou ausência de material transgênico. Embora seja uma prática que determine a presença ou não do material transgênico, ela não identifica se o transgene está ou não integrado ao genoma. O processo permite ampliar um pequeno fragmento de DNA milhares de vezes, permitindo a clonagem deste, o seqüenciamento, a quantificação de seqüências específicas, a analise da expressão gênica por amplificação a partir de um RNA, análise da estrutura do genoma e o diagnóstico de doenças em plantas e animais entre outras (Ferreira e Grattapaglia, 1995).

Outra ferramenta poderosa para análise do transgene é a técnica de Southern blot, a qual oferece condições para a identificação da complexidade da inserção, número de cópias do transgene e número de sítios de integração no DNA genômico. Ela permite detectar fragmentos de DNA específicos em amostras complexas como DNA genômico. As análises de Southern oferecem evidências da integração de genes com maior confiabilidade que o PCR, uma vez que os iniciadores utilizados por este, normalmente amplificam regiões internas do transgene, dificultando a diferenciação entre DNA exógeno integrado e dos contaminantes. 


\section{MATERIAL E MÉTODOS}

O presente trabalho foi desenvolvido nos Laboratórios de Marcadores Moleculares e Micropropagação e de Biologia Molecular do setor de Biotecnologia Agrícola do Departamento de Ciências Biológicas da ESALQ - Universidade de São Paulo (USP) - Campus Piracicaba e no Laboratório de Biologia Molecular do Centro de Tecnologia Copersucar - CTCPiracicaba - SP

\subsection{Fenologia da cana-de-açúcar}

A variedade da cana-de-açúcar usada no projeto foi a Australiana Q117, resultado do cruzamento da Q77 x 58n829, em que o diâmetro do colmo é de médio a grosso, com boa produção de sacarose, baixa tolerância æ̀̀ áreas secas, boa produtividade em áreas chuvosas; demonstra um ótimo comportamento "in vitro" produzindo calos embriogênicos em grande quantidade, embora apresente uma enorme susceptibilidade à ferrugem. Foi cedida pelo Centro de Tecnologia Copersucar - CTC- Piracicaba-SP. 


\subsubsection{Material vegetal}

Os toletes obtidos de cana-de-açúcar da variedade Q117 foram submetidos a choque térmico em banho-maria a $55^{\circ} \mathrm{C}$ por 15 minutos, em seguida, lavados em água corrente por 10 minutos e plantados em bandejas contendo substratos (Plantimax $\mathrm{H}$ ). Permaneceram por 3 meses até atingirem $30 \mathrm{~cm}$ de comprimento, em casa-de-vegetação do Laboratório de Marcadores Moleculares e Micropropagação - LMMM do Departamento de Ciências Biológicas, ESALQ/USP.

\subsection{Obtenção dos calos}

Para obtenção dos calos, foi utilizada a região meristemática da Q117 (região que contém o meristema apical protegido por folhas jovens enroladas), proveniente de plantas com 3 meses, crescidas em casa de vegetação, com mais ou menos $30 \mathrm{~cm}$ de comprimento. Após a retirada das folhas externas, eles ficaram com $15 \mathrm{~cm}$ de comprimento e $2 \mathrm{~cm}$ de diâmetro. Foram esterilizados superficialmente com álcool etílico (80\% por 1 minuto) e, a seguir, com hipoclorito de sódio (15\%), e 200ul de Tween (20\% pôr 15 minutos), sendo feitas três lavagens em câmara de fluxo laminar com água destilada autoclavada.

Logo após, o palmito foi seccionado transversalmente em cortes de aproximadamente $0,2 \mathrm{~cm}$ a $0,3 \mathrm{~cm}$ e esses cortes foram colocados em placa de petri contendo $25 \mathrm{~mL}$ de meio de cultura sólido Cl-3clav (MS modificado de Murashige \& Skoog (1962) suplementado com $3 \mathrm{mg} / \mathrm{L}$ de 2,4-ácido diclorofenoxiacético (2,4-D), $150 \mathrm{mg} / \mathrm{L}$ ácido cítrico, antibiótico Clavulim da Beecham (0,5 g/L) conforme a Tabela 1 e o pH foi ajustado em 5,8 antes da adição do agar para solidificar o meio. Após o preparo, foi esterilizado em 
autoclave por 20 minutos, a $127^{\circ} \mathrm{C}$ ( $\left.1 \mathrm{~atm}\right)$. Os explantes foram mantidos no escuro por 30 dias em sala de crescimento àtemperatura de $25 \pm 2^{\circ} \mathrm{C}$.

Após os 30 dias, os explantes foram repicados e transferidos para meio de cultura fresco e, depois da terceira semana, já se iniciou a formação de calos, que foram repicados a cada 3 semanas. O material oriundo dos explantes continha geralmente dois tipos de calos: um mais friável e translúcido, de comportamento não morfogênico, e outro com aspecto nodular opaco não-friável facilmente destacável da estrutura original, geralmente embriogênico. Foram feitas 5 repicagens desse material $\left(R_{1}, R_{2}, R_{3}, R_{4}, R_{5}\right)$ e utilizados no bombardeamento calos com cerca de 19 semanas de cultivo.

Tabela 1. Meio de cultura Cl3clav.(meio de cultura Cl3, acrescido do antibiótico Clavulin)

meio de cultura $\mathrm{Cl}-3$

(Volume/L do meio)

Água destilada

$800 \mathrm{~mL}$

Sacarose

$20 \mathrm{~g}$

Sol. MACRO nutrientes (MS) $100 \mathrm{~mL}$

Sol. MICRO nutrientes (MS) $10 \mathrm{~mL}$

Sol. Fe/EDTA nutrientes (MS) $20 \mathrm{~mL}$

Sol. Vitaminas (B5G) $1 \mathrm{~mL}$

$2,4-D^{*}$ $300 \mathrm{mg} / \mathrm{L}$

Agar $7 \mathrm{~g}$

Antibiótico Clavulin $0,5 \mathrm{~g} / \mathrm{L}$

* 2,4-D* - ácido 2,4-diclorofenoxiacético

* Antibiótico Clavulin

* Ácido cítrico (10 mg/L) 


\subsection{Plasmídio pAHC17, pXL3 e pHA9}

O plasmídio utilizado foi o pAHC17 - Figura 3 - cedido pelo Engo Agro. Dr. Eugenio Ullian do Centro de Tecnologia - CTC - Copersucar. O plasmídio possui o gene promotor da ubiquitina do milho (ubi 1), e contém um cassete com vários sítios de restrição. Expressa-se somente em monocotiledônea e foi empregado na construção de outros vetores.

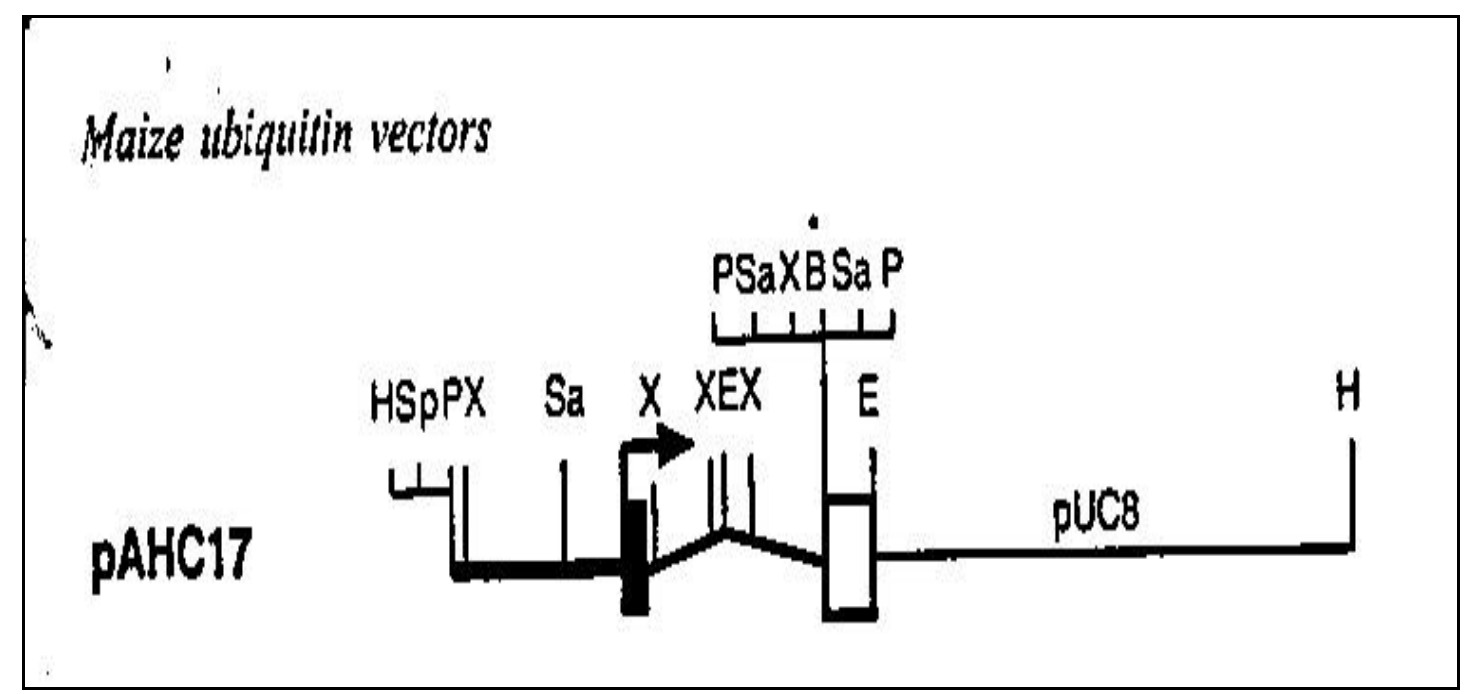

Figura 3 - Esquema representativo do plasmídio pAHC17 (cedido gentilmente pelo Engo ${ }^{-}$Agro. Dr. Eugenio Ullian, Centro de Tecnologia Copersucar), contendo o promotor da ubiquitina do milho (ubi-1) 
O plasmídio $p X L 3$, conforme Figura 4, possui o gene de interesse pr5k que está inserido nas regiões torso e KD. Foi isolado de Arabidopsis thaliana e é um receptor de membrana sinalizador do interior da célula quando ocorre ataque de patógenos. Está relacionado com as proteínas (PR5), envolvidas no sistema de defesa contra microorganismos patogênicos.

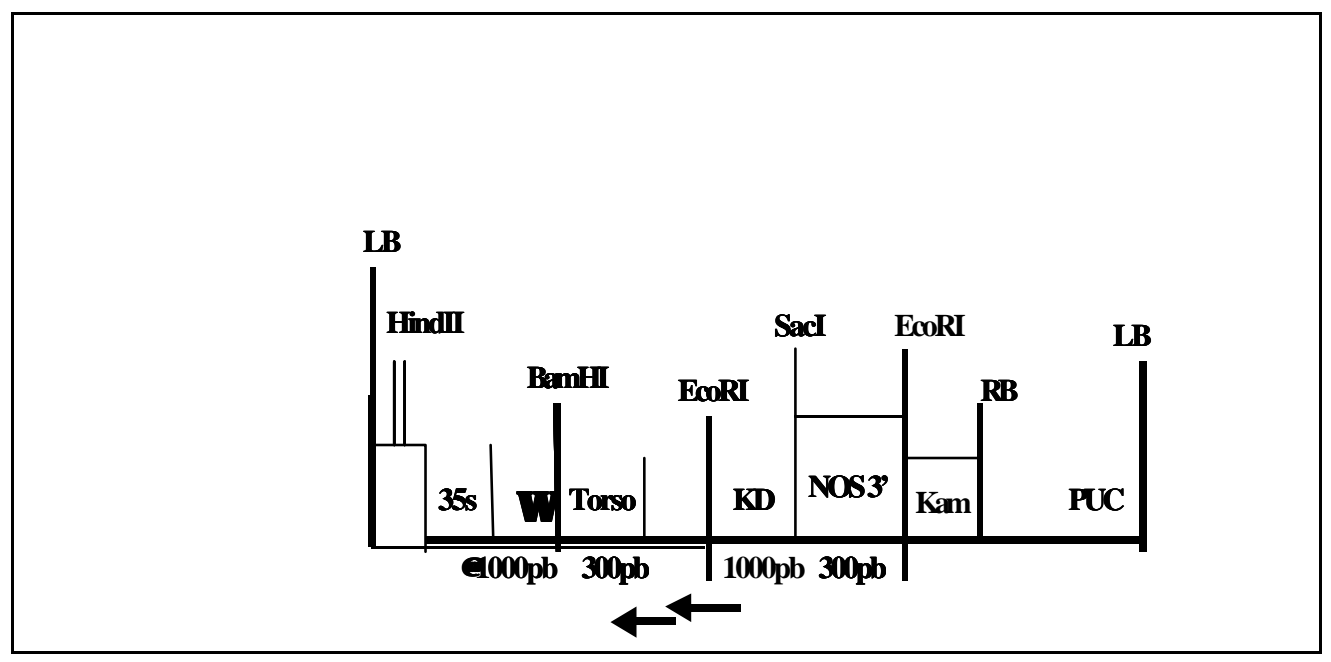

Figura 4 - Esquema representativo do plasmídio pXL3 (cedido pelo Dr. Michael Lawton, Rutgers, NJ.USA) contendo o gene de interesse pr5k, isolado de (Arabidopsis thaliana), está relacionado æ̀ proteínas $P R 5$ que conferem resistência a patógeno 
O plasmídio pHA9 contém o gene marcador de seleção da geneticina e o gene que codifica para a enzima neomicina fosfotrasnferase II (NPT II). Essas enzimas normalmente não são encontradas em plantas e atuam fosforilando o grupo 3'- hidroxil da porção aminohexose de antibióticos aminoglicosilados, como os antibióticos kanamicina A, B e C, neomicina e gentamicina A, (Benveniste \& Davies, 1973; Brasileiro, 1998). É um dos marcadores mais usados para transformação de plantas. (Figura 5)

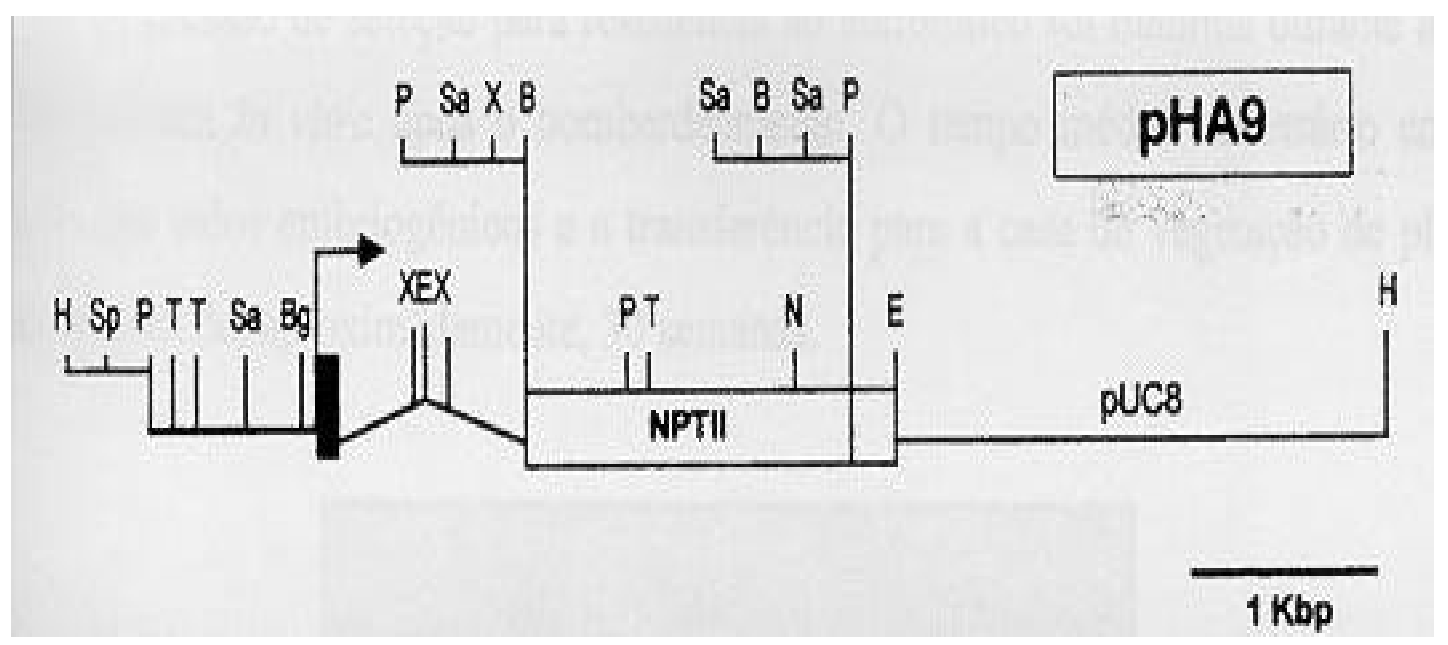

Figura 5 - Esquema representativo do plasmídio pHA9 (cedido pelo Dr. Eugenio Ullian - Centro de Tecnologia - Copersucar - CTC), que contém o gene neo que codificador da enzima neomicina fosfotransferasell (npt II) 


\subsubsection{Digestão do Plasmídio pAHC17 e pXL3 com Enzimas de Restrição BamHI e EcoRI}

Foram feitas digestões com enzimas de restrição BamHI e EcoRI nos plasmídios pAHC17 e pXL3. Nas digestões com BamHI e EcoRI, foram utilizados $5 \mu \mathrm{l}$ de DNA plasmidial. O DNA foi isolado da bactéria E.coli, por meio de miniprep (conforme protocolo estabelecido no laboratório de Biologia Molecular - CEBTEC). Foram acrescentados ao DNA plasmidial $1 \mu$ da enzima BamHI, $2 \mu$ do tampão Reart3 (10x), $12 \mu$ de água MiliQ autoclavada e colocados no Biologic Oxigen Demand - B.O.D por 2 horas a 37ํㅡ. Após a digestão de 2 horas com a enzima BamHI, foi adicionado $1 \mu \mathrm{l}$ da enzima EcoRI

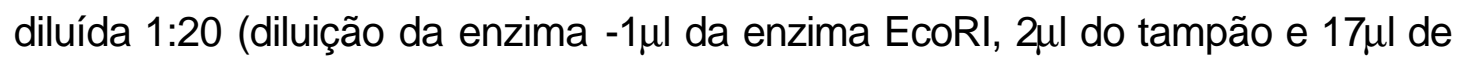
água miliQ) e colocadas novamente no Biologic Oxigen Demand - B.O.D, em três tempos diferentes 5,8 e 10 minutos a $37^{\circ} \mathrm{C}$. Após esse tempo, foram adicionados $3 \mu \mathrm{l}$ de EDTA (10mM) e $3 \mu \mathrm{l}$ de tampão loading, tendo um volume final de $27 \mu$ l. As amostras foram aplicadas em gel de agarose 1,2\% (Tabela 2) (agarose Invitrogem cat.No 15510-019) em uma cuba de eletroforese (cuba para eletroforese da Bio Rad), contendo $40 \mathrm{~mL}$ do tampão de corrida TAE $1 \mathrm{x}$ (Tabela 3), em que foi mantido a uma voltagem de $30 \mathrm{v}$ por $8 \mathrm{hs}$.

Tabela 2. Gel de agarose

Gel de agarose (eletroforese)

$0,8 \%$ de agarose

$40 \mathrm{~mL}$ de tampão TAE $1 \mathrm{X}$

$0,5 \mu \mathrm{l}$ de ETBR (brometo etílico) 
Tabela 3. Tampão de corrida TAE 50X

\begin{tabular}{lc}
\hline Tampão de corrida TAE 50X & (volume/L) \\
\hline água destilada & $500 \mathrm{~mL}$ \\
Tris base & $242 \mathrm{~g}$ \\
ácido acético glacial & $57,1 \mathrm{~mL}$ \\
EDTA 500mM & $100 \mathrm{~mL}$ \\
Completar o volume para 1L com água destilada \\
${ }^{*}$ Para o preparo do tampão de corrida TAE 1x \\
${ }^{*} 20 \mathrm{~mL}$ do TAE 50x \\
${ }^{*} 980 \mathrm{~mL}$ de água destilada
\end{tabular}

\subsection{Clonagem do Inserto no Vetor}

Após a eletroforese, foram retiradas as bandas de interesse dos plasmídeos pAHC17 (4885 pb) e pXL3 (2600 pb), foi feita a purificação dos fragmentos empregando o Kit Clontech ${ }^{\circledR}$ (Núcleo Spin extract kit cat No \#K 3051-1). Após a purificação, o DNA foi conservado a $20^{\circ} \mathrm{C}$ e, em seguida, realizoutse a ligação dos DNAs presentes dos dois plasmídios. Uma reação contendo $3 \mu \mathrm{l}$ de DNA vetor (pAHC17), Gul do DNA gene de interesse pr5k (inserto), $2 \mu \mathrm{l}$ do tampão $\mathrm{T}_{4}$ DNA ligase (buffer), $1 \mu \mathrm{l} \mathrm{T}_{4}$ DNA ligase (Gibco'TM/BRL ${ }^{\circledR}$ ), $1 \mu \mathrm{L}$ DTT e $2 \mu$ l de água MiliQ autoclavada e foi colocada em banho-maria à $16^{\circ} \mathrm{C}$, "over nigth". Na manhã seguinte, foram adicionadas 200 $\mu \mathrm{l}$ de células competentes e colocadas no gelo por 20 a 30 minutos e, em seguida, foram incubados em banho-maria a $42^{\circ} \mathrm{C}$ por 2 minutos. Foram acrescentados $800 \mu \mathrm{l}$ de meio LB (Tabela 4) sem antibiótico e deixadas no Incubator Shaker (New Brunswick Scientific) a $37^{\circ} \mathrm{C}$ por 1 hora. Após esse tempo, as células foram transferidas para placas de petri contendo meio LB 
sólido com antibiótico ampicilina ( $50 \mathrm{mg} / 100 \mathrm{~mL}$ ) e deixadas a $37^{\circ} \mathrm{C}$ no Biologic Oxigen Demand - B.O.D "over nigth". As células que cresceram formaram colônias, as quais foram empregadas para a extração do DNA. A extração ocorreu através do Maxiprep que é um KIT utilizado para extração em grande quantidade de DNA (Plasmid Max Kit cat No 12162 QIAGEN®). Em seguida, foram feitas as digestões com as enzimas de restrição BamHI e EcoRI, para confirmação da inserção do gene de interesse pr5k no vetor pAHC17.

Tabela 4. Meio de cultura para bactéria LB (líquido e sólido)

\begin{tabular}{|c|c|}
\hline Meio para cultura de bactéria LB sólido líquido & volume/L \\
\hline $1 \%$ de Bacto triptona & $10 \mathrm{~g}$ \\
\hline $1 \% \mathrm{NaCl}$ & $10 \mathrm{~g}$ \\
\hline $0,5 \%$ de extrato de levedura & $5 \mathrm{~g}$ \\
\hline Meio para cultura para bactéria LB sólido & volume/L \\
\hline $1 \%$ de bacto triptona & $10 \mathrm{~g}$ \\
\hline $1 \% \mathrm{NaCl}$ & $10 \mathrm{~g}$ \\
\hline $0,5 \%$ de extrato de levedura & $5 \mathrm{~g}$ \\
\hline bacto agar & $20 \mathrm{~g}$ \\
\hline
\end{tabular}

\subsubsection{Preparação das partículas de tungstênio para o bombardeamento}

Após a clonagem do inserto ao vetor, o DNA plasmidial que contém o gene de interesse e o plasmídio pHA9 que contém o gene neo que codifica a enzima neomicina fosfotransferase II (NPT I), gene de resistência a geneticina, 
foram preparados para 0 bombardeamento. Esses plasmídios foram precipitados em partículas de tungstênio (60 $\mu \mathrm{l}$ da solução), através da mistura de cloreto de cálcio $(50 \mu \mathrm{g}$ de solução $2,5 \mathrm{M}$ ), 10 $\mu \mathrm{g}$ de DNA, $20 \mu \mathrm{l}$ de espermidina "free base" (0,1 M). Essa mistura foi centrifugada a $11200 \mathrm{~g}$ (10000 rpm) durante 1 minuto e o pellet foi lavado duas vezes com etanol absoluto e duas vezes em etanol $95 \%$, sendo ressuspendido em $30 \mu$ de etanol $100 \%$.

Quatro microlitros desta mistura foram utilizados no bombardeamento de cada placa de petri. Os calos embriogênicos foram posicionados no centro da placa, formando um círculo, em que as partículas de tungstênio contendo o DNA plasmidial foram bombardeadas àpressão de $7 \mathrm{kgf} / \mathrm{cm}^{2}$.

\subsection{Escolha da fase de subcultivo para bombardeamento}

Dos calos repicados a cada 3 semanas foram selecionados os embriogênicos e os restantes transferidos para meio Cl-3clav (meio de cultura Cl-3 acrescido do antibiótico clavulin). Após 19 semanas esses calos foram selecionados e transferidos para o meio de cultura $\mathrm{Cl}-3 \mathrm{OS}$ (meio de cultura contendo manitol e sorbitol $36,4 \mathrm{~g} / \mathrm{L}$ ) quatro horas antes do bombardeamento. $\mathrm{O}$ meio de cultura $\mathrm{CH} 3 \mathrm{OS}$ aumenta a osmolaridade da célula ocorrendo uma plasmólise que facilita a penetração das partículas de tungstênio sem a degradação da parede celular e a membrana da célula.

Após o bombardeamento dos calos de cana-de-açúcar, os mesmos foram transferidos para meio de cultura $\mathrm{Cl}-3$ (meio de cultura $\mathrm{Cl} 3 \mathrm{MS}$ modificado), sem 2,4-D. 


\subsection{Aparelho de biolística}

O aparelho utilizado para o bombardeamento foi desenvolvido pelo Centro de Tecnologia da Copersucar, e emprega para o envio das partículas, gás Helio comprimido com vácuo parcial, de acordo com as instruções de Finer et al (1992).

Para os bombardeamentos foram utilizados calos embriogênicos de cana-de-açúcar, em placa de petri de plástico com meio de cultura $\mathrm{Cl} 3 \mathrm{sem}$ 2,4-D e acrescidos de manitol e sorbitol. Foram utilizadas partículas de tungstênio envolvidas com o DNA transformante, de acordo com o método descrito por (Santford et al., 1993). A distância entre o tecido alvo foi da $5^{a}$ prateleira $\pm 15 \mathrm{~cm}$, numa pressão de $\left(7 \mathrm{Kgf} / \mathrm{cm}^{2}\right)$. Foi utilizada uma agulha de seringa para o disparo e o vácuo de $26 \mathrm{mmHg}$.

Logo após o bombardeamento os calos de cana-de-açúcar foram transferidos para meio Cl-3 acrescido de 2,4-D (ácido 2,4-diclorofenoxiacético), $3 \mathrm{mg} / \mathrm{L}$ e mantidos no escuro por 10 dias em sala de crescimento. Passados os 10 dias, esses mesmos calos foram transferidos para meio $\mathrm{Cl} 3$ acrescido de 2,4-D (3 mg/L), mais o antibiótico de seleção geneticina $35 \mathrm{mg} / \mathrm{mL}$ e mantidos em sala de crescimento num fotoperíodo de $14 \mathrm{~h}$ de luz/10 h de escuro e temperatura de $25 \pm 2^{\circ} \mathrm{C}$ para seleção dos transformantes.

\subsection{Regeneração das plantas}

Os calos de cana-de-açúcar que cresceram em meio de seleção foram considerados transformantes. Foram, em seguida, transferidos para meio $\mathrm{Cl}-3$ com BAP (6-Benziladeninopurina), mais o antibiótico de seleção geneticina (cat No 11811-023 Invitrogem Coporation) $35 \mathrm{mg} / \mathrm{mL}$, para crescimento e 
regeneração de plantas. Foram mantidos em sala de crescimento em fotoperíodo de $14 \mathrm{~h}$ de luz/10 $\mathrm{h}$ de escuro á temperatura de $25 \pm 2^{\circ} \mathrm{C}$, até as plântulas atingirem $4 \mathrm{~cm}$ de altura, quando foram analisadas em nível de PCR para a confirmação da ocorrência de inserção do gene de interesse.

\subsection{Preparo do DNA da planta (MINIPREP)}

O DNA usado para análise, via PCR, foi extraído de acordo com o protocolo de Doyle \& Doyle ( 1990)

As folhas de cana-de-açúcar foram trituradas em tubo eppendorf de 1 $\mathrm{mL}$. Foram adicionados $500 \mu \mathrm{l}$ de tampão mix (Tabela 5) e deixadas em incubação por 15 minutos a $60^{\circ} \mathrm{C}$. Em seguida, foi incubado por 1 minuto no gelo e, após esse período, foram adicionados $400 \mu$ l de clorofórmio e centrifugado a $12000 \mathrm{~g}$ (11400 rpm), por 5 minutos, em temperatura ambiente. O sobrenadante foi transferido para outro tubo de eppendorf e adicionaram-se $400 \mu \mathrm{l}$ de isopropanol. Centrifugourse por $12000 \mathrm{~g}$ (11400 rpm), por 5 minutos à temperatura ambiente. Neste estagio ocorreu a presença de um precipitado (pellet). Descartou-se o sobrenadante com muito cuidado e adicionaram-se 500 $\mu \mathrm{l}$ de etanol a $70 \%\left(-20^{\circ} \mathrm{C}\right)$. Centrifugou-se por $12000 \mathrm{~g}(11400 \mathrm{rpm})$, por 3 minutos, e foi descartado o sobrenadante. O "pellet" foi seco à temperatura ambiente por 20 minutos, quando o mesmo foi ressuspendido em $20 \mu l$ de água MiliQ autoclavada. 
Tabela 5. Buffer Mix para extração de DNA de plantas

\begin{tabular}{lcc}
\hline & Tampão de extração (MIX) & $100 \mathrm{~mL}$ \\
\hline CTAB & & \\
NaCL & $2 \%$ & $2 \mathrm{~g}$ \\
EDTA & $1,4 \mathrm{M}$ & $28 \mathrm{~mL}$ \\
Tris/HCL pH 8,0 & $20 \mathrm{mM}$ & $4 \mathrm{~mL}$ \\
$\beta$-mercaptoetanol & $100 \mathrm{mM}$ & $10 \mathrm{~mL}$ \\
\hline
\end{tabular}

\subsection{Analise da integração por PCR}

Após a transformação genética da cana-de-açúcar, as plantas regeneradas em meio de cultura seletiva contendo geneticina $(35 \mathrm{mg} / \mathrm{mL})$ foram analisadas em nível de PRC para determinar se houve a integração do transgene no genoma da cana-de-açúcar. Utilizando-se primers específicos para a amplificação da região da construção, as plantas transformadas com o plasmídio pRGA (plasmídio construído com o gene de interesse) foram submetidas à análise utilizando os primers pRI e pRII D12(5' CTCTCACGGCACGGCAGCTA 3') e E01 (5' ACCACCGGGTCAGCCGTCCG 3'), que permitem a amplificação de uma região de aproximadamente $1450 \mathrm{pb}$ até $3700 \mathrm{pb}$, que correspondem a um fragmento do gene pr5K e parte do promotor da ubiquitina do milho (Tabela 6).

Para confirmar se as plantas foram realmente transformadas ou não, procedeu-se a extração do DNA de acordo com o protocolo estabelecido (Plant DNA MINIPREP), descrito por Doyle \& Doyle (1990), em que foram realizados dois tipos de reações de PCR no aparelho de PCR da GeneAmp ${ }^{\circledR}$ PCR System 9700. Na primeira reação do PCR, utilizou-se a seguinte condição 
:10 pMoles dos primers $(1 \mu \mathrm{l}$ do pRI e do pRII) $1 \mu \mathrm{l}$ dNTP $(5 \mathrm{mM}), 4 \mu \mathrm{l}$ de DNA que corresponde a $50 \mathrm{ng} / \mu \mathrm{l}$ de DNA genômico; 0,3 U de enzima Taq DNA polimerase (PROMEGA), $3 \mu$ de tampão buffer de reação 10x (Gbco) e 0,75 $\mu$ l de $\mathrm{MgCl}_{2}(50 \mathrm{mM})$ em um volume final de $30 \mu \mathrm{l}$. A amplificação foi realizada nas condições: desnaturação a 94ํㅡ por 30 segundos; 35 ciclos constituídos de: desnaturação a $94^{\circ} \mathrm{C}$ por 1 minuto, anelamento a $57^{\circ} \mathrm{C}$ por 1 minuto , e a extensão da fita DNA polimerase a $72^{\circ} \mathrm{C}$ por 1 minuto e, por último, a extensão final a $72^{\circ} \mathrm{C}$ por 5 minutos a $4^{\circ} \mathrm{C}$.

A segunda reação do PCR foi realizada nas seguintes condições: 10 pMole dos primers (pRil e pRII), $3 \mu$ do tampão buffer de reação $10 \times\left(\mathrm{Gbco}^{\mathrm{TM}}\right)$; $0,9 \mu \mathrm{l}$ de $\mathrm{MgCl}_{2}$ (50 mM); 1,2 $\mu \mathrm{l}$ de dNTP (5 mM); $2 \mu$ de DNA genômico; 0,3 U da enzima Taq DNA polimerase; 20,6 $\mu$ de $\stackrel{\text { }}{\mathrm{O} O}$ MiliQ autoclavada, em um volume final de $30 \mu \mathrm{l}$. A amplificação foi realizada nas seguintes condições: desnaturação a 94ํ $\mathrm{C}$ por 2 minutos, constituído de 35 ciclos de desnaturação a $94^{\circ} \mathrm{C}$ por 45 segundos, anelamento a $60^{\circ} \mathrm{C}$ por 30 segundos, e a extensão da fita de DNA polimerase a $72^{\circ} \mathrm{C}$ por 4 minutos, e por ultimo, a extensão final da fita a $72^{\circ} \mathrm{C}$ por 2 minutos e, $4^{\circ} \mathrm{C}$, onde uma alíquota de $15 \mu$ la reação foi aplicada em gel de agarose $0,8 \%$.

Tabela 6. Listas dos plasmídios com os respectivos primers e temperatura de anelamento respectivos (TM)*.

\begin{tabular}{|c|c|c|}
\hline Plasmídio & Primer 1 ( 5' - 3' ) & $\mathrm{TM}^{*}$ \\
\hline \multirow[t]{2}{*}{ pAHC17 } & PR1 & \\
\hline & CTCTCACGGCACGGCAGCTA & $57 \mathrm{C}$ e $60 \mathrm{C}$ \\
\hline \multirow[t]{2}{*}{ pXL3 } & $\begin{array}{l}\text { Primer 2 ( 5' - 3' ) } \\
\text { E01 }\end{array}$ & \\
\hline & ACCACCGGGTCAGCCGTCCG & $57 \mathrm{C}$ e 60 \\
\hline
\end{tabular}




\section{RESULTADOS E DISCUSSÃO}

\subsection{Material vegetal obtido em casa de vegetação}

Toletes de cana-de-açúcar da variedade Q117 foram mantidos em bandejas com substrato Plantimax $\mathrm{H}$ e mantidos em casa de vegetação com sistema de irrigação. Foram obtidas plântulas de $30 \mathrm{~cm}$ de altura as quais foram utilizadas no experimento para obtenção dos calos.

\subsection{Cultura de tecido para cana-de-açúcar}

Neste trabalho, foram utilizados os palmitos de cana-de-açúcar secionados em cortes transversais de $0,3 \mathrm{~cm}$ e inoculados em meio de cultura Cl-3clav contendo 2,4-D (3 mg/L), acrescido do antibiótico Clavulin (0,5 g/L) para que não ocorressem contaminações. (Figura 6)

Um aspecto muito importante nessa variedade de cana-de-açúcar é a liberação de compostos fenólicos, resultando ra necessidade de adição do ácido cítrico (10 mg/L), ao meio de cultura, para se evitar assim o processo de oxidação dos explantes. $O$ ácido cítrico tem a função antioxidante e também de reduzir espécies reativas do oxigênio produzidas enzimaticamente ou não após o corte dos explantes e a exposição dos mesmos ao ar. Este reagente tem o poder de proteger os explantes que são submetidos á cultura in vitro. 


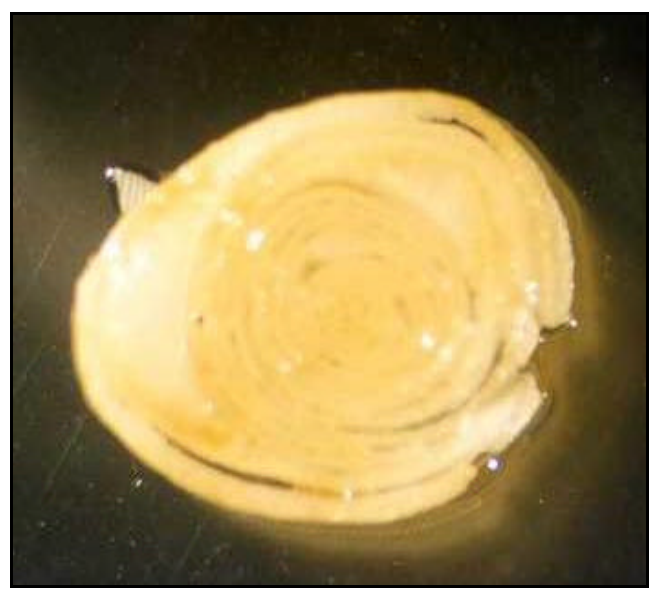

A

B

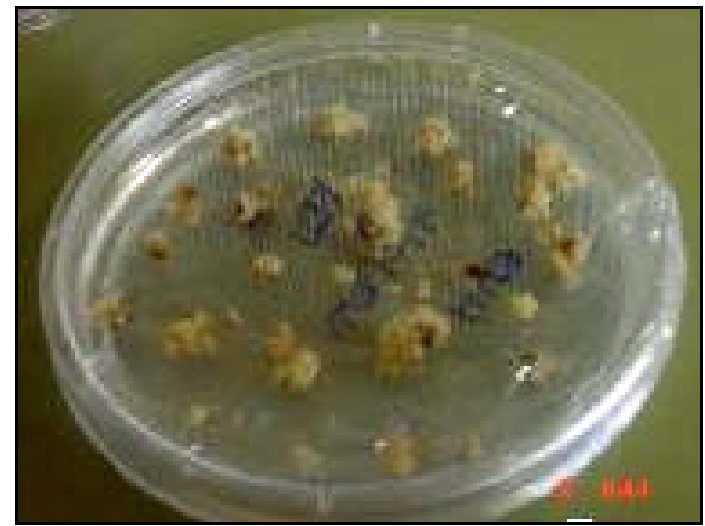

Figura 6 - Palmitos de cana-de-açúcar em meio de cultura Cl-3 clav acrescidos de 2,4-D e mantidos no escuro por 30 dias

A - Palmitos recém inoculados

B - Calos com 30 dias de cultivo

Estes calos foram mantidos em sala escura a $25 \pm 2^{\circ} \mathrm{C}$ por 30 dias, quando a primeira repicagem foi realizada. Os mesmos foram repicados a cada 3 semanas. A Figura 7 mostra explantes da variedade Q117 com duas semanas em meio de cultura Cl-3clav (meio de cultura $\mathrm{Cl} 3$ com antibiótico clavulin) e a formação inicial dos calos. 


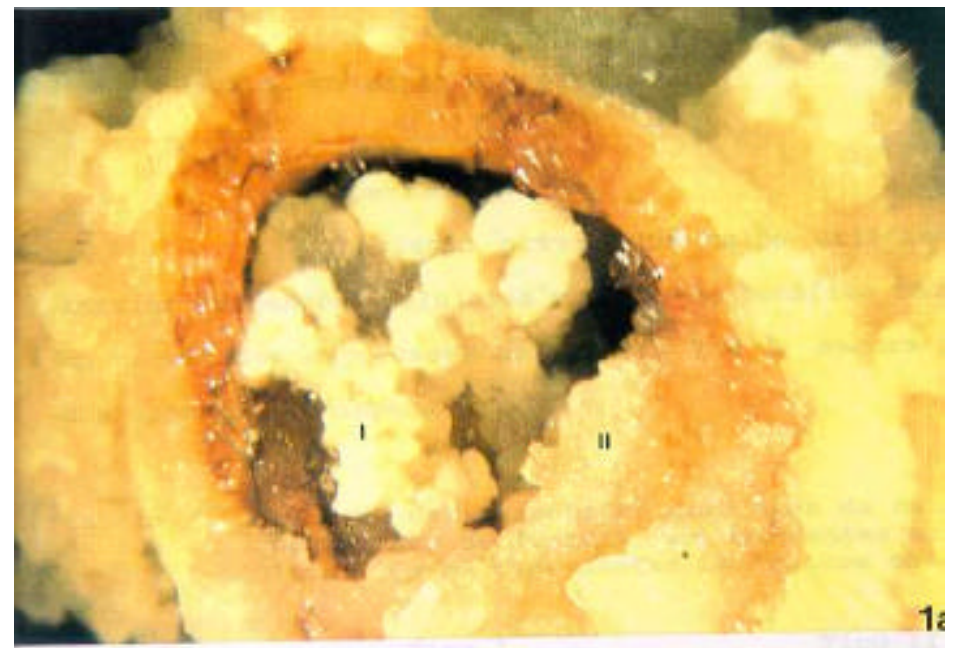

Figura 7 - Calos de cana-de-açúcar da variedade Q117 apresentando formação inicial de calos após 30 dias

Após cinco repicagens, foi selecionado o material embriogênico que consistia dos calos com cerca de 3 a 19 semanas. Os mesmos foram utilizados nos experimentos de bombardeamento. A Figura 8 mostra calos embriogênicos da variedade Q117

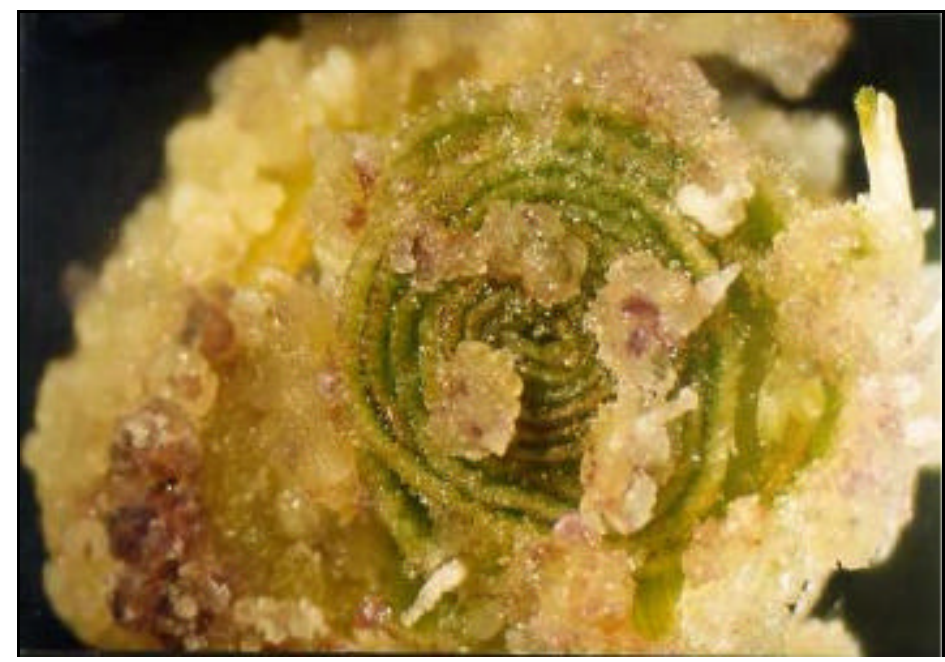

Figura 8 - Calos embriogênicos da variedade Q117, após 4 repicagens (16 semanas) em meio de cultura Cl3 clav acrescido de 2,4-D (3 $\mathrm{mg} / \mathrm{L})$ 


\subsection{Plasmídios}

No trabalho, foi utilizado o plasmídio pAHC17 com 5180 pb, o qual possui um cassete com vários sítios de restrições, contendo o gene promotor da ubiquitina do milho (ubi-1), que só se expressa em monocotiledônea. $O$ plasmídio possui sítios de restrição para as enzimas BamHI e EcoRI. O mesmo foi digerido com as enzimas de restrição BamHI e EcoRI (conforme protocolo citado) e as amostras foram aplicadas em gel de agarose 1,2\%. Após a corrida, obteve-se o fragmento de interesse que é de $\mathbf{4 8 8 5}$ pb.

A Figura 9 mostra o tamanho do fragmento obtido.

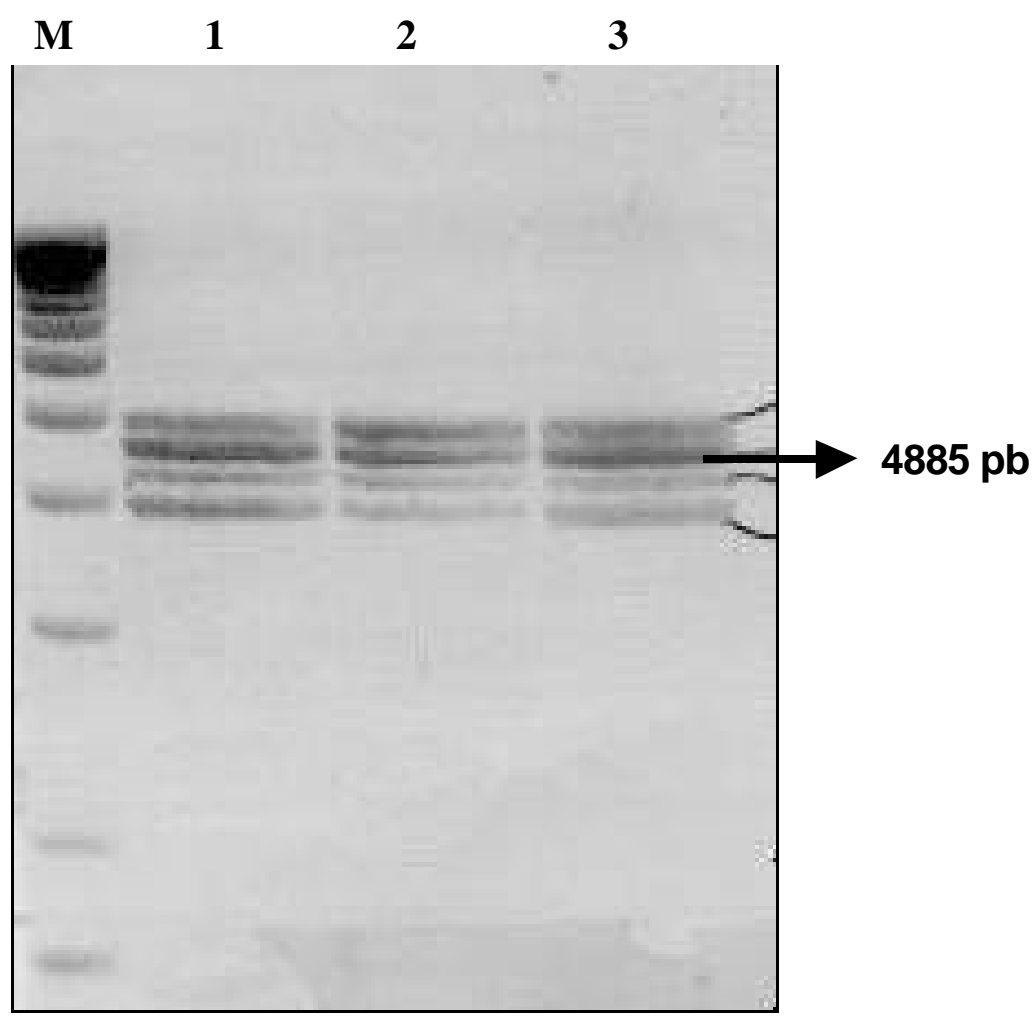

Figura 9 - Tamanho do fragmento obtido do plasmídio (pAHC17). $M=1 \mathrm{~Kb}$ DNA ladder, pela digestão com enzimas de restrição BamHI e EcoRl e o fragmento com 4885 pb. (1 a 3 = repetições) 
O plasmídio pXL3 contém o gene de interesse $P R 5 K$, inserido na região do TORSO e KD e possui o promotor constitutivo, como o 35s, do vírus do mosaico da couve-flor (CaMV), que só se expressa em dicotiledônea. Por isso foi utilizado o pAHC17 que contém o promotor da ubiquitina do milho (ubi1), que se expressa em monocotiledônea (Sanford et al., 1993; Birch, 1997). O plasmídio possui vários sítios de restrições onde foram feitas as digestões com as enzimas de restrição BamHI e EcoRI. As amostras foram aplicadas em gel de agarose 0,8\% obtendo um fragmento de 2600 pb conforme Figura 10, que corresponde ao fragmento que contém o gene de interesse que é o PR5K.

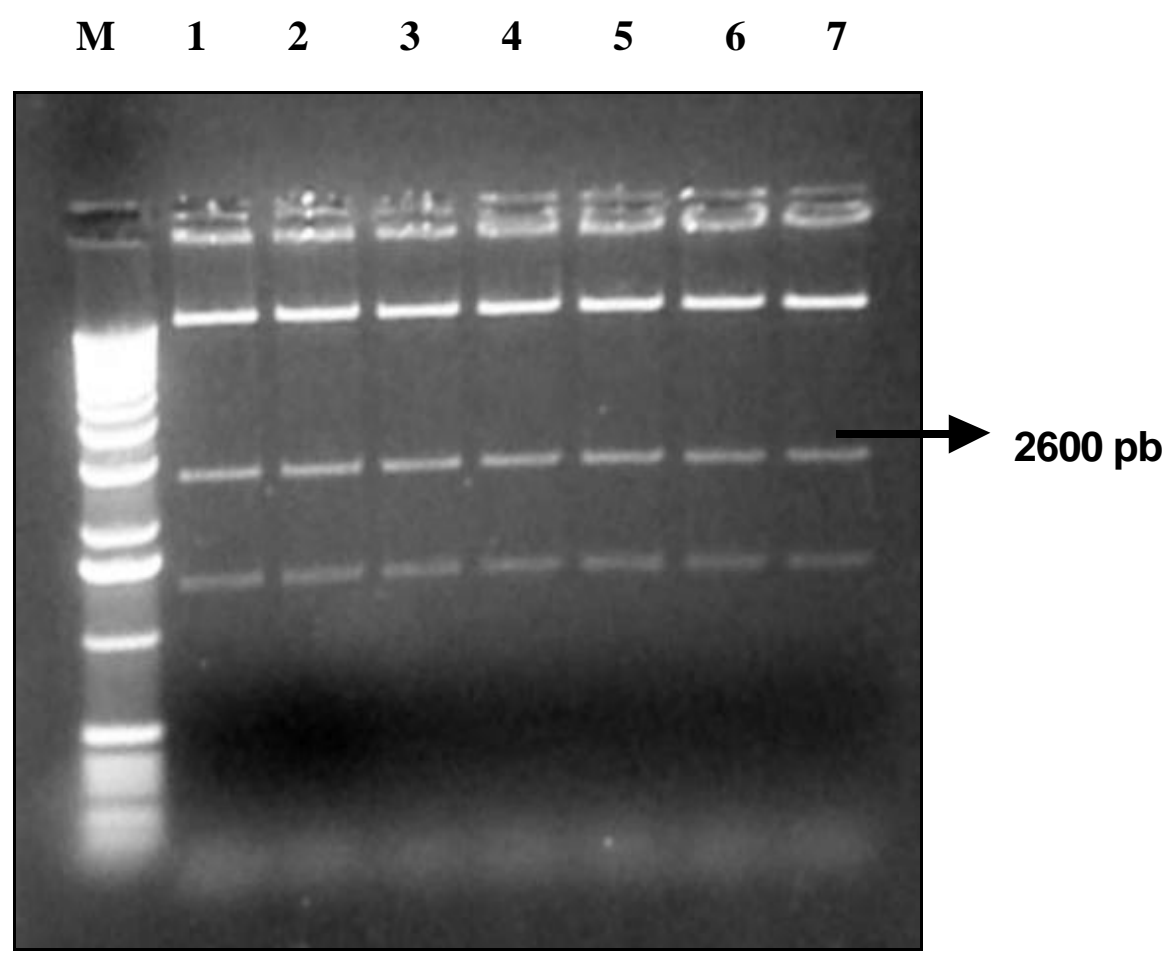

Figura 10 - Fragmento obtido do plasmídio pXL3 (2600 pb) M = 1Kb de DNA ladder. As numerações de 1 a 7 são repetições contendo os fragmentos de 2600 pb que contêm o gene de interesse PR5K 


\subsection{Confirmação da inserção do pR5K no vetor pAHC17}

Para confirmar se o inserto, que é o gene pR5K, foi mesmo inserido no pAHC17 (plasmídio vetor), após a purificação dos fragmentos os mesmos com o Kit Clontech®,( Núcleo Spin extract kit cat No \# K 3051-1). Foram feitas as digestões em três tempos diferentes com as enzimas de restrições BamHI e EcoRI.

Para a digestão com a enzima BamHI (2 h), foi obtido o fragmento de interesse de 7485pb. Já, para BamHI e EcoRI (2 h), foram produzidos os fragmentos de 4272pb, 2600pb, 613pb. Com EcoRl (2 h), os fragmentos foram de 4272pb e 3213pb. Na Figura 11, temos um gel de agarose para a confirmação da inserção do fragmento de interesse no plasmídio vetor. A Figura 12 representa um esquema da construção do novo plasmídio pRGA, que foi obtido pela inserção do pR5K ao plasmídio vetor pAHC17 (item 3.4). O mesmo foi digerido com as enzimas de restrição BamHI e EcoRI, nos tempos citados na Figura 11, a partir do qual podemos concluir que houve a inserção do fragmento de 2600 pb no pasmídio vetor, correspondente ao gene PR5K, que foi utilizado para o bombardeamento dos calos de cana-de-açúcar da variedade Q117 


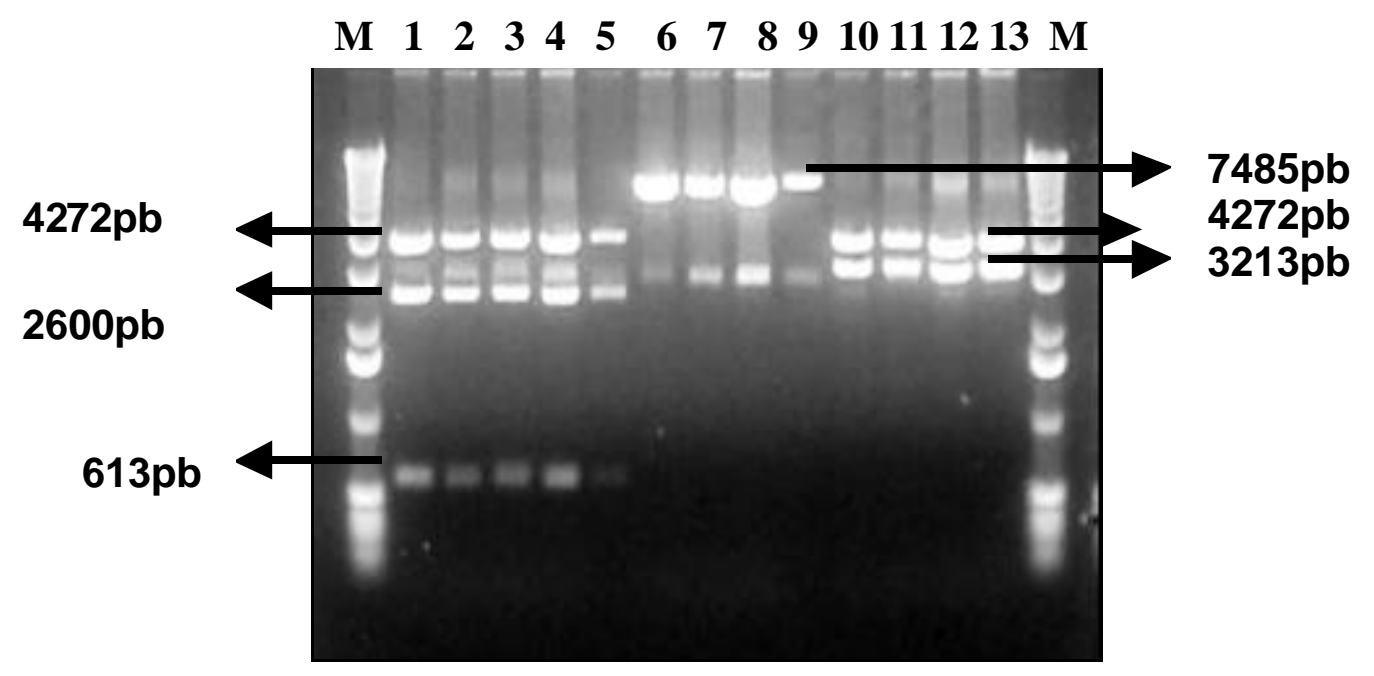

Figura 11 - Confirmação da inserção do gene de interesse pR5K (inserto) no plasmídio pAHC17 (vetor) - M = 1kb ladder, (1 a 5) digestão com BamHI e EcoRl (2 h), e o fragmentos são 4272pb, 2600pb, 613pb, (6 a 9)digestão com BamHI (2 h) com o fragmento 7485pb, (10 a 13) digestão com EcoRI (2 h) com o fragmento 4272pb e 3213pb - $\mathrm{M}=1 \mathrm{~kb}$ ladder

PAHC17 pR5K

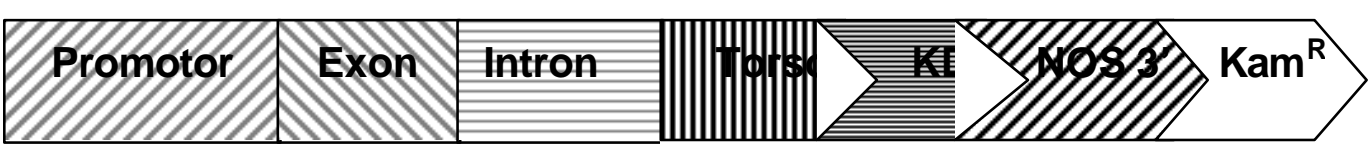

Figura 12 - Esquema da construção do pRGA - contendo o pAHC17 com 4885 pb mais o gene de interesse pR5K 2600 pb - plasmídio contendo no total $7485 \mathrm{pb}$ 


\subsection{Bombardeamento dos calos embriogênicos de cana-de-açúcar}

Os calos embriogênicos selecionados (Figura 13), após 4 repicagens (19 semanas), foram transferidos para meio de cultura Cl-3OS (meio de cultura Cl-3 contendo manitol e sorbitol), posicionados em círculos formando um alvo no centro das placas de petri com cerca de $4 \mathrm{~cm}$ de diâmetro. $O$ tratamento dos calos, antes e após o bombardeamento, pode influir na freqüência de transferência de genes. Por isso o uso do meio de cultura $\mathrm{Cl} 3 \mathrm{OS}$ teve por objetivo aumentar a pressão osmótica do meio de cultura das células antes do bombardeamento, resultando numa freqüência significativa na transformação (Smith et al., 1992; Russell et al., 1992b; Vain et al., 1993b; Kemper et al.,1995).

Vain et al,(1993b) demonstrou que a elevada pressão osmótica do meio de cultura protege a célula do impacto da onda de choque pela diminuição do tugor, facilitando assim a penetração das partículas de tungstênio recobertas com o DNA plasmidial no espaço nuclear

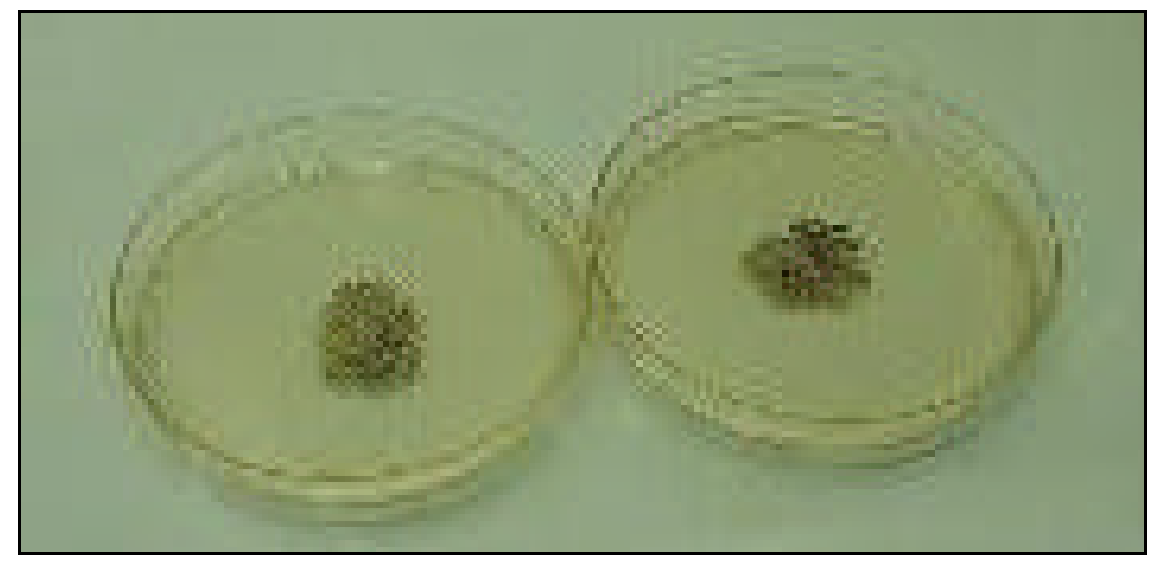


Figura 13 - Calos de cana-de-açúcar em meio de cultura Cl3OS, 4 horas antes do bombardeamento

\subsection{Otimização do protocolo para o bombardeamento}

Foi estabelecido um protocolo, com base nos resultados de eficiência de expressão transiente em experimentos com o gene uid-A, realizados no inicio dos trabalhos na Copersucar, em que o revólver de genes utilizado nos experimentos foi construído a partir de um trabalho publicado por Finer et al (1992).

Foram utilizados no bombardeamento $4 \mu$ lde DNA plasmidial (pRGA) contendo o gene de interesse pr $5 k, 4 \mu \mathrm{l}$ do plasmídio pHA9 que contém o gene de resistência à canamicina e o gene neo que codifica a enzima neomicina fosfotransferase II ( NPT II). Os disparos foram realizados numa câmara de vácuo para minimizar a resistência do ar e a aceleração das partículas de tungstênio com o DNA plasmidial (pRGA), e o pHA9, em uma pressão de saída de gás hélio comprimido de7 $\mathrm{kgf} / \mathrm{cm}^{2}$, a distância do alvo foi da $5^{\text {a }}$ prateleira $( \pm 15 \mathrm{~cm})$ e a distancia entre as placas contendo os calos embriogênicos foi a mesma para os dois experimentos, e vácuo de $26 \mathrm{mmHg}$.

Os calos bombardeados foram transferidos para meio de cultura $\mathrm{Cl} 3$ acrescidos de $3 \mathrm{mg} / \mathrm{L}$ de 2,4-D e mantidos no escuro em sala de crescimento à temperatura de $25 \pm 2^{\circ} \mathrm{C}$ por 10 dias.

\subsection{Seleção dos calos para resistência ao antibiótico geneticina}


$\mathrm{Na}$ seleção dos calos de cana-de-açúcar em meio de cultura contendo o antibiótico geneticina, empregou-se um protocolo usado pela Copersucar sendo que Falco (1998) demonstrou a eficiência do agente seletivo em seu trabalho para seleção de calos de cana-de-açúcar.

No presente trabalho, os calos bombardeados foram transferidos para meio de cultura $\mathrm{Cl} 3$, suplementado de $3 \mathrm{mg} / \mathrm{L}$ de 2,4-D e mantidos em sala de crescimento no escuro, àtemperatura $25 \pm 2^{\circ} \mathrm{C}$ por 10 dias.

Após os 10 dias, os mesmos foram transferidos para meio de cultura com 2,4-D e $35 \mathrm{mg} / \mathrm{mL}$ de antibiótico geneticina (meio de cultura Cl3Gen), mantidos em sala de crescimento com fotoperíodo de 14:10h e temperatura $25 \pm 2^{\circ} \mathrm{C}$, com trocas regulares de meio de cultura a cada duas semanas. Após este período, $40 \%$ dos calos apresentaram aspecto normal

A geneticina mostrou-se ser um eficiente agente seletivo (Figura 14), em relação a kanamicina que se tem mostrado pouco eficaz como agente seletivo em gramíneas, quando a mesma foi comparada com espécies dicotiledônea. Segundo Nehra et al (1994),a melhor opção em antibiótico para monocotiledônea é a geneticina, que não interfere no processo de regeneração, podendo ser usado em processo seletivo em estágios iniciais. Partindo desse princípio, optou-se por utilizar o antibiótico geneticina no meio de cultura para confirmação de plantas possivelmente transformadas a partir de calos de cana-de-açúcar bombardeada.Também serão elaborados testes foliares com o fungo pulverizado nas plantas transformadas em casa de vegetação. 


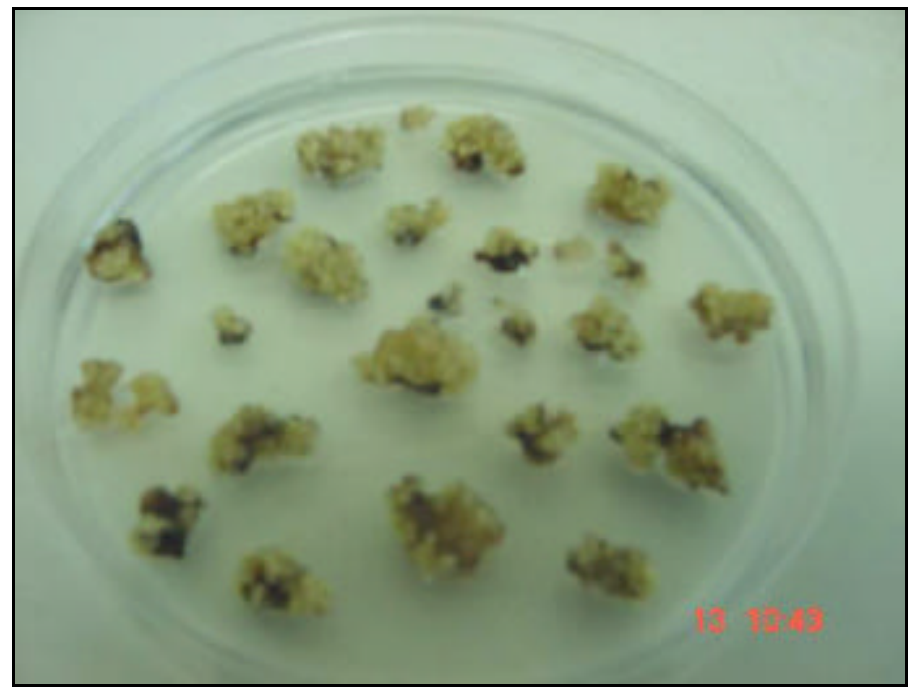

Figura 14 - Calos de cana-de-açúcar bombardeados em meio de cultura $\mathrm{Cr}$ 3Gen2,4-D e mantidos em sala de crescimento fotoperíodo de $14 \mathrm{~h}$ Luz :10 h escuro, à temperatura de $25 \pm 2^{\circ} \mathrm{C}$

Após 6 semanas, com trocas regulares de meio de cultura a cada duas semanas, os calos foram transferidos para meio de cultura de regeneração. Nesta fase, o 2,4-D foi retirado de sua composição, enquanto que BAP (5 mg/L), foi adicionado (meio de cultura Cl3GenBAP). Os calos foram mantidos nestas condições, por um mês, em sala de crescimento, fotoperíodo de $14 \mathrm{~h}$ de luz / $10 \mathrm{~h}$ de escuro e à temperatura de $25 \pm 2^{\circ} \mathrm{C}$, com o meio de cultura sendo trocado a cada duas semanas (Figura 15). 


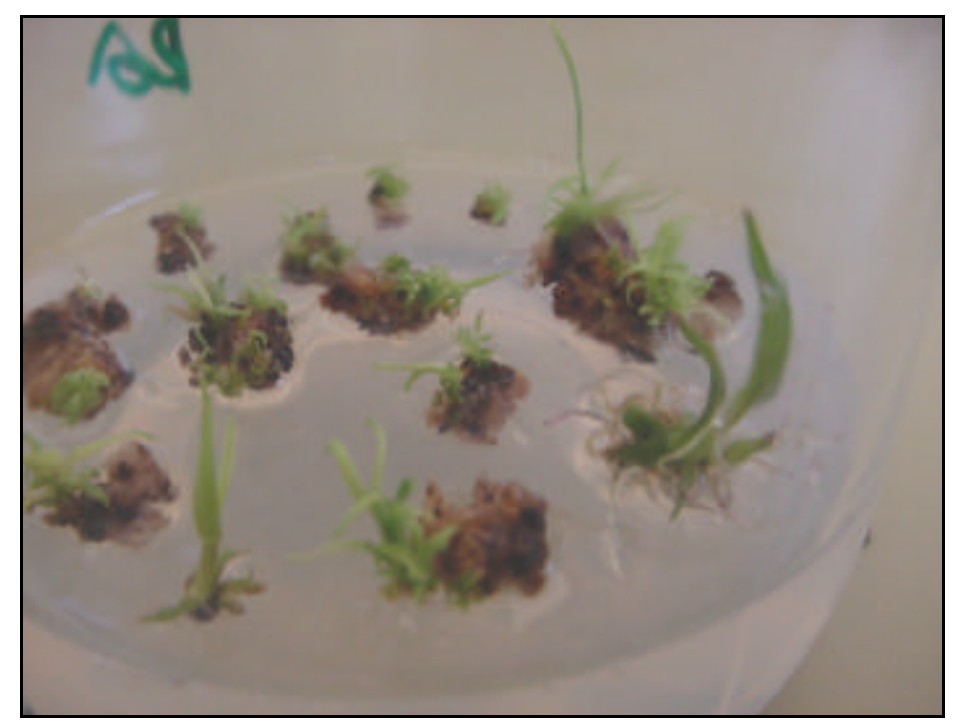

Figura 15 - Plantas possivelmente transformadas e regeneradas, de calos selecionados do meio de cultura Cl-3Gen com 2,4-D, suplementado com BAP. A pressão de seleção foi mantida para que plantas "escape" fossem selecionadas, identificadas e descartadas

Os calos embriogênicos resistentes à geneticina originaram plantas possivelmente transformadas (Quadro 1), que foram selecionadas e colocadas em tubetes com meio de cultura Cl3 GenBap, em que o 2,4-D foi retirado da composição e acrescido de BAP $5 \mathrm{mg} / \mathrm{L}$. Como se pode observar pela Figura 13 , alguns calos foram resistentes à geneticina e são plantas possivelmente transformadas com o gene de interesse pr5k e o gene de seleção para geneticina. As plantas regeneradas podem ser observadas na Figura 16. Estas plantas foram submetidas a um PCR para confirmação da transformação e integração do DNA exógeno ao genoma da cana-de-açúcar. Plantas de canade-açúcar da variedade Q117, sem nenhum processo de transformação, foram usadas como controle na análise de PCR (Figura 17). 


\begin{tabular}{|l|c|c|c|c|c|c|}
\hline Experimentos & $\begin{array}{c}\text { Quantida } \\
\text { de placas } \\
\text { bombar } \\
\text { deadas }\end{array}$ & $\begin{array}{c}\text { Quantidade } \\
\text { de calos } \\
\text { por placas }\end{array}$ & $\begin{array}{c}\text { calos não } \\
\text { regenera } \\
\text { dos. }\end{array}$ & $\begin{array}{c}\text { Calos } \\
\text { regenera } \\
\text { dos. }\end{array}$ & $\begin{array}{c}\% \text { não } \\
\text { regene } \\
\text { rados. }\end{array}$ & $\begin{array}{c}\% \\
\text { regenera } \\
\text { dos. }\end{array}$ \\
\hline Experimento I & 18 & 10 & 170 & 10 & $95 \%$ & $5 \%$ \\
Experimento II & 40 & 10 & 341 & 59 & 85,25 & $14,75 \%$ \\
$\%$ & & & & & \\
\hline
\end{tabular}

Quadro 1. Quantidade de placas bombardeadas, número de calos por placa e percentual de calos não regenerados para regenerados de placas.

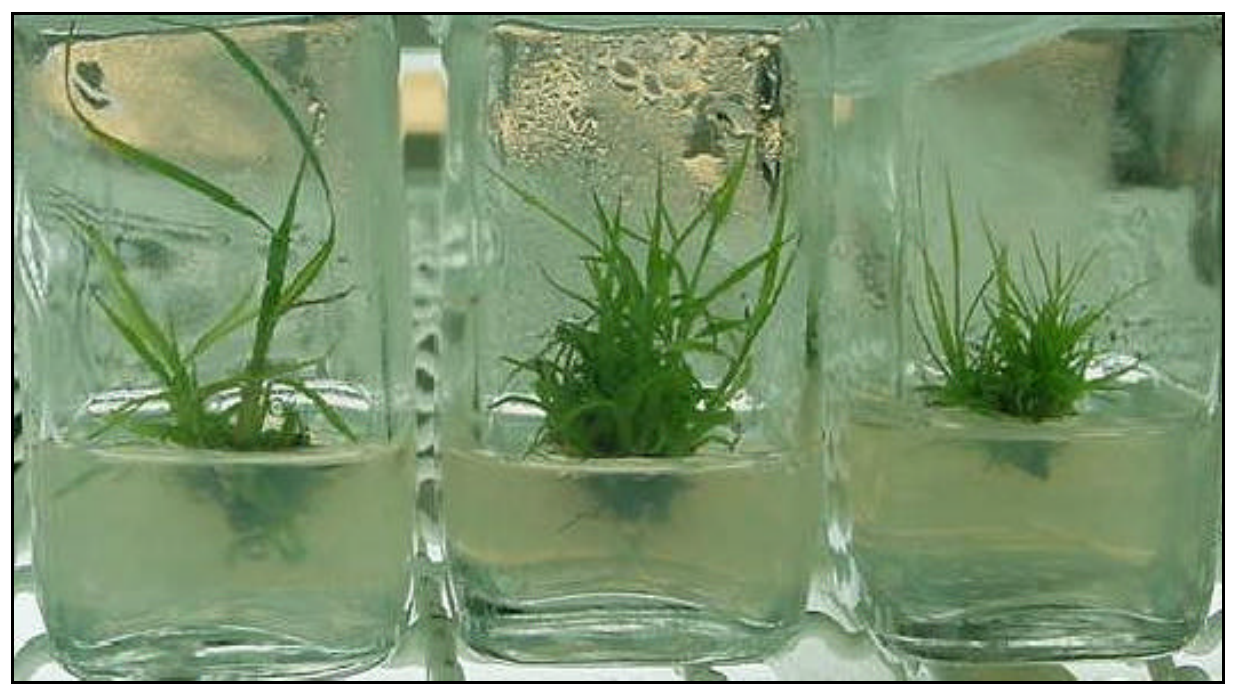

Figura 16 - Plantas que sofreram seleção com geneticina, enraizadas em meio Cl-3GenBap. A pressão de seleção foi mantida e as mesmas foram analisadas em nível de PCR, para identificar a inserção do gene PR5K no genoma da cana-de-açúcar 


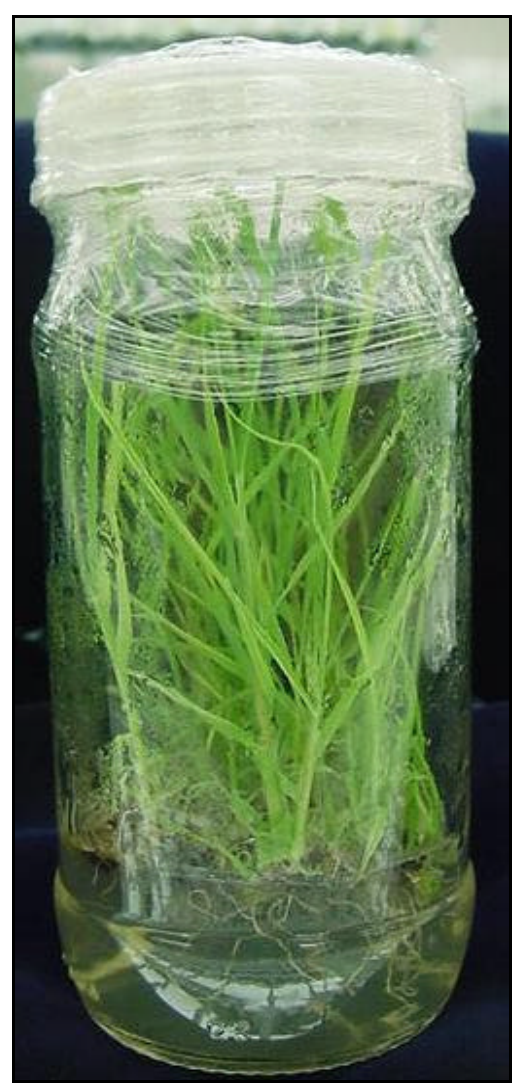

Figura 17 - Plantas de cana-de-açúcar da variedade Q117, crescendo "in vitro", que foram empregadas em análise do PCR como controle

\subsection{Análise do DNA - método PCR}

Plântulas de cana-de-açúcar da variedade Q117, possivelmente transformadas com o gene de interesse pr5k, foram analisadas por PCR (reação em cadeia da polimerase) empregando dois primers (D12 5' CTCTCACGGCACGGCAGCTA 3') e E01 5 'ACCACCGGGTCAGCCGTCCG 3'). As reações foram realizadas no aparelho Programable Thermal Controler 
(MJ Research Incorporation), utilizando o protocolo de reações e as condições citadas no item 3.9. Podemos observar, então na Figura 18, que não só existem algumas bandas das plantas possivelmente transformadas, mas também várias regiões amplificadas em relação às analisadas, a região esperada \pm 1600 pb. Notamos que o PCR não ficou muito específico. Foram testadas várias temperaturas de anelamento e a que mostrou maior eficiência foi a de $60^{\circ} \mathrm{C}$.

\section{$\begin{array}{lllllllll}M & C & 26_{1} & 26_{2} & 26_{4} & 23_{3} & \mathrm{H}_{2} \mathrm{O} & \mathrm{P}\end{array}$}

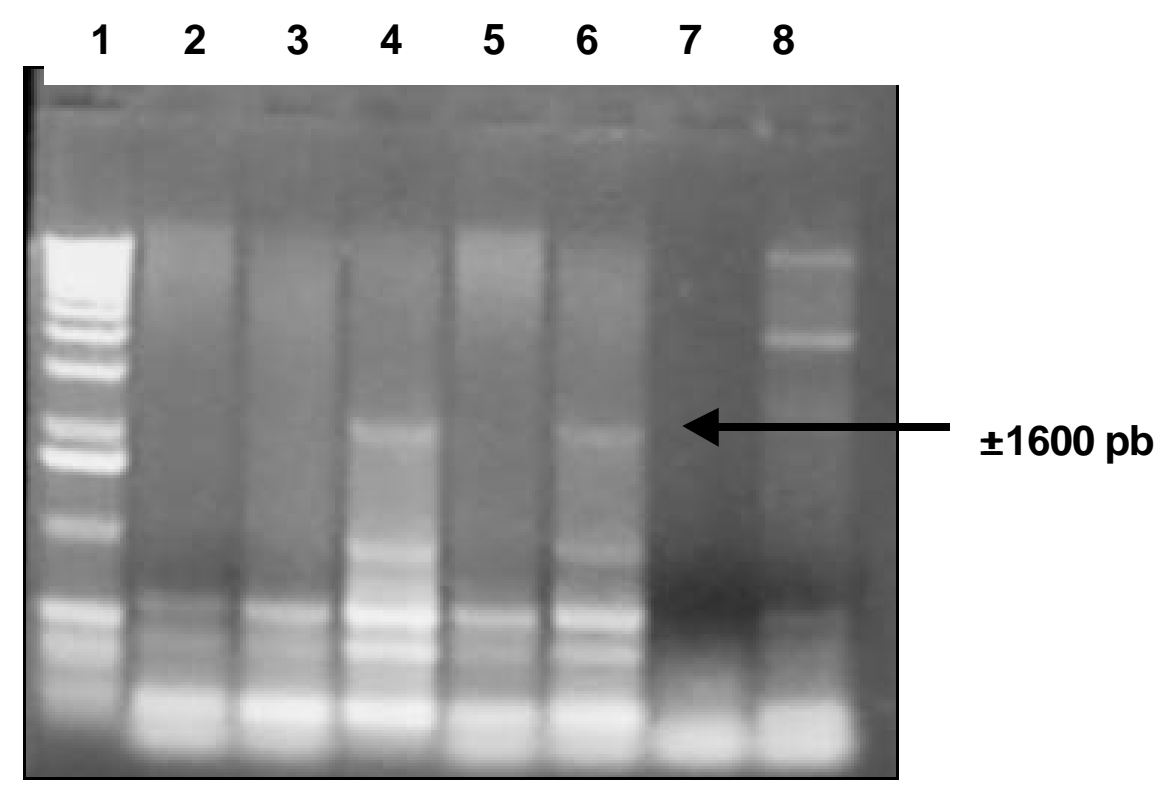

Figura 18 - Regiões amplificadas por PCR a partir de DNA genômico, referentes ao promotor D12 e E01. M: linha 1 DNA ladder ; linhas 3 a 6 amostras de plantas possivelmente transformadas; linha 2: controle positivo (planta não transformada); linha 7: água destilada (controle negativo); $\quad$ 8: plasmídio pRGA 
Também foi feito um PCR de gradiente das amostras 23 e 26 que são as possivelmente transformadas (Figura 19), testando várias temperaturas de $57^{\circ} \mathrm{C}$ a $67^{\circ} \mathrm{C}$, onde notamos que a temperatura ótima permaneceu entre $58^{\circ} \mathrm{C}$ a $62^{\circ} \mathrm{C}$. Está sendo otimizado um protocolo, aumentando a concentração da reação, para que possamos obter um resultado preciso.
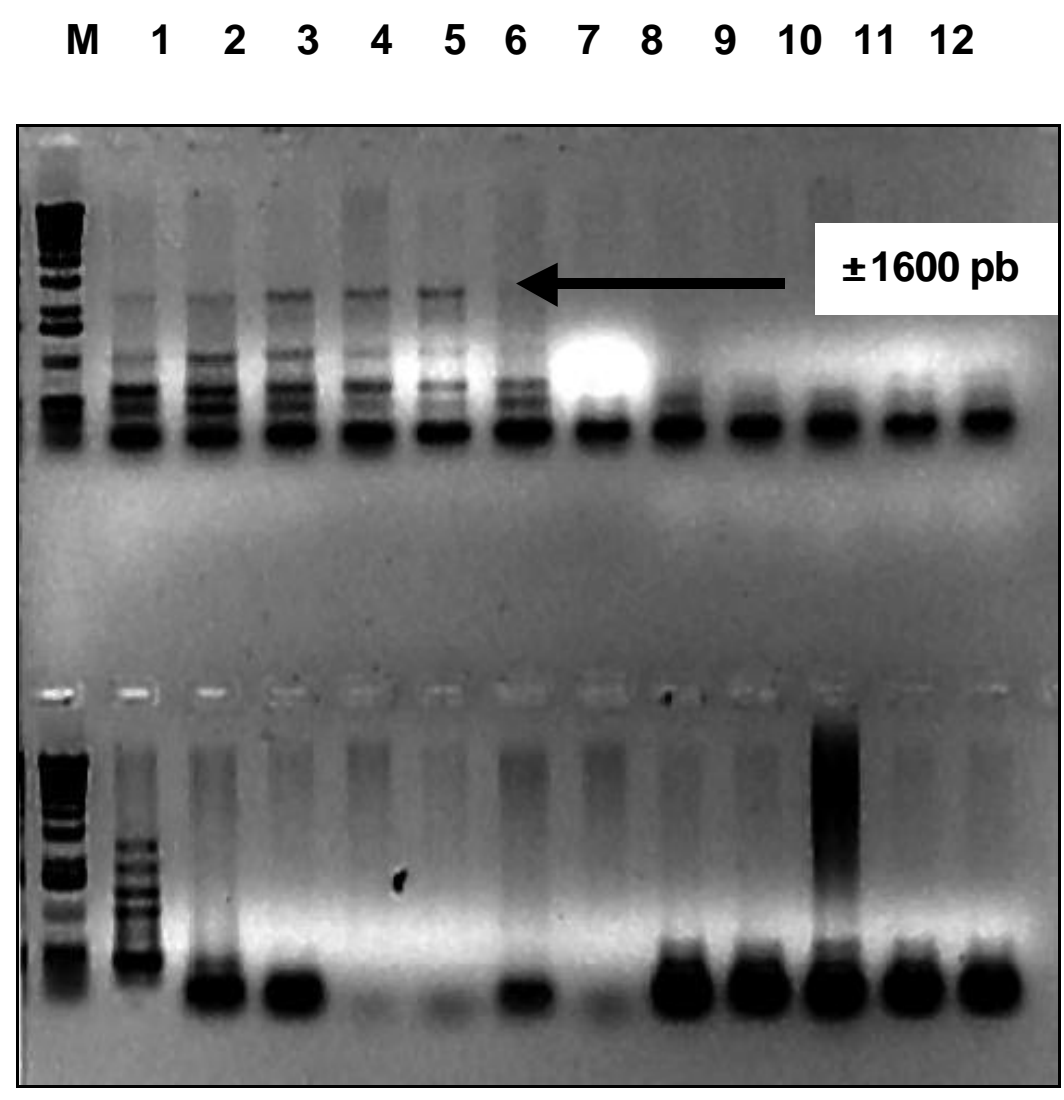

A

B

Figura 19 - PCR de gradiente: (A) - amostras das plantas possivelmente transformadas da placa 23 - (B) - Amostras das plantas da placa 26 possivelmente transformadas, onde foram feitos testes de temperaturas entre 57 a $67^{\circ} \mathrm{C}$ 


\section{CONCLUSÕES}

De acordo com os resultados obtidos nos experimentos realizados concluiurse que:

$\Rightarrow$ O protocolo desenvolvido para obtenção de calos embriogenicos de cana-de-açúcar da variedade australiana Q117, mostrou-se eficiente na obtenção dos mesmos. É adequado para uso em experimento de transformação genética desta espécie.

$\Rightarrow A$ análise das plantas em nível de PCR, embora não muito específicos demonstraram que há possibilidades de algumas plantas serem trangênicas.

$\Rightarrow$ Os resultados demonstram a eficiência na obtenção dos calos de cana-de-açúcar da variedade Q117, e também no percentual de regeneração das mesmas que após o bombardeamento com os plasmídios pRGA e pHA9, foi de $\pm 20 \%$ do total dos experimentos. A análise em nível de PCR revelou que,não só existem algumas bandas mas plantas possivelmente transformadas, mas também várias regiões amplificadas em relação à analisadas,. Foram testados várias temperaturas de anelamento e a que mostrou maior eficiência foi de $60^{\circ} \mathrm{C}$. 
$\Rightarrow$ Dos calos bombardeados com o plasmídio pRGA que contém o gene de resistência a geneticina, foram obtidos $\pm 1 \%$ de plantas resistentes e possivelmente transformadas. Testes em casa de vegetação deverão ser realizados para a confirmação final da transformação. 


\section{REFERÊNCIAS BIBLIOGRÁFICAS}

AGRIOS, G.N. Plant pathology. San Diego: Academic Press, 1997. 635p.

ANDERSON, A.J. Elicitors, the hypersensitive response and phytoalexins. In: Keen, N.T.; Kosuge, T.; Walling, L.L. (Ed.). Physiology and biochemistry of plant-microbial interactions. Local: American Society of Plant Physiologists, 1988 p.103-109.

ANGENON, G.; DILLEN, W.; MONTAGU, M. VAN. Antibiotic resistance markers for plant transformation. In: GELVIN, S.B.; SCHILPEROORT, R.A. (Ed.). Plant molecular biology manual. Dordrecht: Kluwer Academic, 1994. Section C1, p.1-13.

ARENCIBA, A.D.; CARMONA, E.R.; TÉLLEZ, P.; CHAN, M-T.; YU, S_M.; TRUJILLO, L.E.; ORAMAS, P. An efficient protocol for sugarcane (Saccharun ssp.L.) transformation mediated by Agrobacteriun tumefaciens. Transgenic Research, v.7 p.213-222, 1998.

ARENCIBA, A. Molecular analysis of the genome of transgenic rice (Oryza sativa L.) plants produced via particle bombardment or intact cell electroporation. Molecular Breeding, v. 4, p. 99-109, 1998. 
BENVENISTE, R.; DAVIES, J. Mechanisms of antibiotic resistance in bacteria. Annual Review of Biochemistry, v.42, p.471-506, 1973.

BERGAMIN FILHO, A.; KIMATI, H.; AMORIM, L. Manual de fitopatologia. 3.ed. São Paulo : Agronômica CERES, 1995. v.1, p.872-880: Ferrugem.

$\mathrm{BIRCH}$, R.G. New gene technologies and their potential value for sugarcane. Outlook on Agriculture, v.25, n.4, p. 219-226, 1996

$\mathrm{BIRCH}$, R.G. Plant transformation: problems and strategies for practical application, Annual Review of Plant Physiology and Plant Molecular Biology, v.48, p.297-326, 1997.

BIRCH, R. G.; FRANKS, T. Development and optimization of microprojectile systems for plant genetic transformation. Australian Journal of Plant Physiology, v. 18, p. 453-469, 1991.

BIRCH, R. G.; BOWER, R.; ELLIOT, A.; POTIER, B.; FRANKS, T.; CORDEIRO, G. Expression of foreign genes in sugarcane. In: CONGRESS OF THE INTERNATIONAL SOCIETY OF SUGARCANE TECHNOLOGISTS, 22., Cali, 1995. Proceedings. Cali: Tecnicanã, 1995. v.2, p.369-373.

BOWER, R.; BIRCH, R. Transgenic sugarcane plants via microprojectile bombardment. Plant Journal, v.2, p.409-416, 1992.

BOWLES, D.J. Defense-related proteins in higher plants. Annual Review of Biochemistry, v.59, p.873-907, 1990. 
BRASILEIRO, A.C.M. Manual de transformação genética de plantas. Brasília : EMBRAPA, CENARGEN, 1998. 309p.

CARVALHO, L.C.C. perpectivas da cultura de cana-de-açúcar para a década de noventa. In: CAMARA ,G.M.S.; OLIVEIRA,E.A.M. (Ed.). Produção de canade-açúcar. Piracicaba: FEALQ, 1993. p.1-17.

CHANG, H.H.; CHAN, M.T. Improvement of potato (Solanum tuberosum.L.) Transformation efficiency by Agrobacteriun in the presence of silver thiosulfate Botanical Academy Sinica, v.32, p.63-70, 1991.

CHESTER, K.S. The problem of acquired physiological immunity in Plants. Quarterly Review of Biology, v.8, p.275-324, 1933.

CHOWDHURY, M.K.U.; VASIL, I.K. Stably transformed herbicide resistant callus of sugarcane via microprojectile bombarment os cell suspension cultures and electroporation of protoplasts Plant Cell Reports, v.11, p.494498, 1992.

COLLINGE, D.B.; KRAGH, K.M.; MIKKELSEN, J.D.; NIELSEM, K.K.; RASMUSSEM, U.; VAD, K. Plant chitinases. The Plant Journal, v.3, n.1, p.31-40, 1993.

COLSON, E.; DEVERALL, B. Helping plant fight their own disease battles. Australian Cottongrower, v.17, p.76-80, 1996.

CRUZ, M.M. Ferrugem e carvão: novas ameaças à produtividades da cana-deaçúcar em Alagoas. Maceió: UFAL, CECA, 1992. 20p. 
DANIELS, J.; ROACH, B.T. Taxonomy and evolution. In: HEINZ, D.J (Ed.). Sugarcane improvement though breeding. Amsterdam: Elsevier, 1987. p.7-84.

DAVIS, B.D. The lethal action of aminoglycosides. Journal of Antimicrobial Chemotherapy, v.22, p.1-3, 1988.

DEMPSEY, D.A; SILVA, H.; KLESSIG, D.F. Engineering disease and pest resistance in plants. Trendes in Microbiology, v.6, n.2, p.54-61, 1998.

DIXON, M.S.; JONES, D.A.; KEDDIE, J.S.; THOMAS, C.M.; HARRISON, K.; JONES, J.D.G. The tomato $C f 2$ disease resistance locus comprises two functional genes encoding leucin-rich repeat proteins. Cell, v.84, p.451-459, 1996.

DIXON, R.A.; LAMB, C.J.; MASOUD, S.; SEWALT, V.J.H.; PAIVA, N.L. Metabolic engineering: prospects for crop improvement through the genetic manipulation of phenylpropanoid biosynthesis and defense responses $-\mathrm{a}$ review. Gene, v.179, p.61-71, 1996.

DOMINGUEZ, A.; GUERRI, J.; CAMBRA, M.; NAVARRO, L.; MORENO, P.; PENA, L. Efficient production of transgenic citrus plants expressing the coat protein gene of citrus trusties virus. Plant Cell Reports, v.19, n.4, p.427-433, 2000.

DOYLE, K; DOYLE, J. Plant DNA miniprep. Focus, v.12, p.1, 1990. 
ELLIOT, A.; CAMPBELL, J.A.; BRETTELL, R.I.S.; GROF, C.P.L. Agrobacterium-mediated transformation of sugarcane using GFP as a screenable marker Australian Journal of Plant Physiology, v.25, p.739743, 1998.

EVANS, D. A.; CROCOMO, O. J.; CARVALHO, M. T. V. Protoplast isolation and subsequent callus regeneration in sugarcane Zeitschrift fuer Pflanzenphysiologie , v. 98, n.4, p. 355-358,1980.

FALCO, M. C. Transformação de cana de açúcar para resistência ao herbicida glufosinato de amônio, via biolística. Piracicaba, 1998. 129p. Tese (Doutorado) -Escola Superior de Agricultura "Luiz de Queiroz", Universidade de São Paulo,

FALCO, M. C.; MENDES, B. M. J.; TUlMANN NETO, A.; GLÓRIA, B. A. Histological characterization of "in vitro" regenation of Saccharum sp. Revista Brasileira de Fisiologia Vegetal, v.8, n.2, p. 93-97, 1996.

FALCO, M.C.; TULMANN NETO, A.; ULIAN, E.G. Transformation and expression of a gene for herbicide resistance in a Brasilian sugarcane. Plant Cell Reports, v.19, p.1188-1194, 2000.

FERNANDES, V. Secapi é aberta com discussão política. Jornal de Piracicaba, Piracicaba, 27 jul. 1999. p.D-1. Suplemento Especial.

FERREIRA, M.E., GRATTAPAGLIA, D. Introdução ao uso de marcadores RAPD e RFLP em análise genética. Brasília: EMBRAPA, CENARGEN, 1995, 220p. 
FINER - MOORE, K.; BA, J.; MORTEZAEI, R.; RICH, D.H.; STROUD, R.M. Episelection: novel $\mathrm{Ki}$ approximately nano molar inhibitors of serine proteases selected by binding or chemistry on an enzyme surface. Biochemistry, v.34, p.8264-8280, 1995.

FLOR, H.H. Inheritance of reaction to rust in flax - 3. Agricultural Research, v.74, n.9 - 10, p.211-263, 1947.

FLOR, H.H. The complementary genetic systems in flax rust. Advances Genetics, v.8, p.156-159, 1956.

FLOR, H.H. The current status of the gene for gene concept. Annual Review of Phytopathology, v.9, p.275-296, 1971.

FODOR, J.; JOZZA, A.; KIRALY, Z. Systemic acquired disease resistance in plant. Novenyvedelem, v.34, p.117-126, 1998.

GAMBLEY, R. L.; FORD, R.; SMITH, G. R. Microprojectile transformation of sugarcane meristems and regeneration of shoots expressing $\beta$ glucuronidase. Plant Cell Reports, v. 12, p. 343-346, 1993.

GAUMANN, E. Pflanzliche infektionslehre.Basel: Birkhauser, 1946. 611p.

GOTO, M. Fundamentals of bacterial plant pathogens San Diego: Academic Press, 1990. 342p.

GATEHOUSE, A.M.R.; GATEHOUSE, J.A. Identifying proteins with insecticidal activity:use of encoding genes to produce insect-resistant transgenic crops Pesticide Science, v.52, p.165-175, 1998. 
GRANT, M.R.; GODIARD, L.; STRAUBE, E.; ASHFIEID, T.; LEWAID, J.; SATTLER, A.; INNES, R.W.; DANGL, J.L. Structure of the Arabidopsis RPM 1 gene enabling dual specificity disease resistance. Science, v.269, p.843846, 1995.

GRIVET, L.; ARRUDA, P. Sugarcane genomics: depicting the complex genome of an important tropical crop. Current Opinion of Plant Biology, v.5, p.122127, 2001.

GURI, A.; SINK, K. C. Agrobacterium transformation of eggplant. Journal of Plant Physiology, v.133, p.52-55, 1988.

HAMMOND-KOSACK, K.E.; TANG, S.; HARRISON, K.; JONES, J.D.G. The tomato Cf9 disease resistance gene functions in tobacco and potato to confer responsiveness to the fungal avirulence gene product Avr9. The Plant Cell, v.10, p.1251-1266, 1998.

JEFFERSON, R.A.; KAVANAGH, T.A.; BEVAN, M.W. GUS fusion: $\beta$ glucuronidase as a sensitive and versatile gene fusion marker in higher plants. EMBO Journal, v.6, p.3901-3907, 1987.

KEMPER, E.L.; SILVA,M.J. da; ARRUDA, P. Effect of microprojectile bombardment parameters and osmotic treatment on particle penetration and tissure damage in transformed cultured immature maize (Zea mays $\mathrm{L}_{\mathbf{i}}$ ) embryos. Plant Science, 1995. v.121, n.1, p.85-93

KIMATI, H.; AMORIM, L.; BERGAMIN FILHO, A.; CAMARGO, L.E.A; REZENDE, J.A.M. Manual de Fitopatologia. 3. ed. São Paulo: Agronômica CERES, 1997. v.2, p. 207-225: Doenças da Cana-de-açúcar. 
KIRALY, Z.; SOLIMOSY, F.; VOROS, J. Methods in plant pathology Budapest: Akademiai Kiadó, 1970.509p.

KOMBRINK, E.; SOMSSICH, I.E. Defense responses of plants to pathogens. Advanced in Botanical Research, v.21, p.2-34, 1995.

KLEIN, T. M.; GRADZIEL, T.; FROMM, M. E.; SANFORD, J. C. Factors influencing gene delivery into Zea mays cells by hight-velocity microprojectiles. Biotechnology, v. 6, p. 559-563, 1988.

MATSUOKA,S. Análise Retrospectiva de perdas causadas pela Ferrugem da cana-de-açúcar em São Paulo. In: CONGRESSO NACIONAL DA STAB, Águas de São Pedro: 1993. Anais,Piracicaba: STAB, 1993. p.148-156.

MOORE, P. H. Progress in sugarcane molecular biology. In: COCK, J. H., T. (Ed.). In: CONGRESS OF THE INTERNATIONAL SOCIETY OF SUGARCANE TECHNOLOGISTS, 22., Cali, 1996. Proceedings. Cali: ISSCT, 1996. v. 2, p. 353-362.

MOURQUES, F.; BRISSET, M.N.; CHEVREAU, E. Strategies to improve plant resistence to bacterial diseases through engineering. Trends in Biotechnology, v.16, n.5, p.203-210, 1998.

MULLER, K. O.; BORGES, H. Experimentelle Unntersuchugen uber die Phytophthora - resistencz der kartoffel. Arbiten der Biologischen reichsaustalt, Land-und Forstwirtschaft, v.23, p.189-231, 1940.

MURASHIGE, R.; SKOOG, F. A revised method for rapid growth and bioassays with tissue cultures. Plant Physiology, v.15, p.473-497, 1962. 
MURASHIGUE, T.; SKOOG, F. A revised medium for rapid growth and bioassay with tobacco tissue culture. Physiology Plantarum, v. 15, p. 473-497, 1962.

NEHRA, N.S.; CHIBBAR, R.N.; LEUNG, N.; CASWELL, K.; MALLARD, C.; STEINHAUER, L.; BAGA, M. AND KARTHA, K.K. (1994). Self-fertile transgenic wheat plants regenerated from isolated scutellar tissues from microprojectile bombardment with two distinct gene constructs. Plant Journal, v. 5, p.285 -297.

OOMMEN, A.; DIXON, R. A.; PAIVA, N. L. The elicitor-inducible alfalfa isoflavone reductase promoter confers different patterns of development expression in homologous and heterologous transgenic plants. Plant Cell, v. 6, p.1789-1803, 1994.

PAULOT, V.; HOLZER, F.M.; REISCH, B.; WALLING, L.L. Leucine aminopeptidase: an inducible component of the defence response in Lycopersicon esculentum (Tomato). Proceedings of the National Academy Science of the USA, v.90, p.9906-9910, 1993.

RAIZER, A.J. Interações genótipos $x$ ambientes e estabilidade fenótipo em cana-de-açúcar no Estado de São Paulo. Piracicaba, 1998. 103p. Dissertação (Mestrado) - Escola Superior de Agricultura "Luiz de Queiroz", Universidade de São Paulo.

REAM, W.; GELVIN, S.B. Crow gall: Advances in understanding interkingdon gene transfer. Saint Paul: APS Press, 1996. 148p.

REGISTER III, J.C. Approachs to evaluating the transgenic status of transformed plants. Trends in Biotechonology, v.15, p.141-146, 1997. 
RIDE , J.P. Cell Walls and other structural barriers in defense. In CALLOW, J.A. (Ed.). Biochemical plant pathology, New York: Willey-Interscience, 1983. p.215-236.

RITCHIE, S.W.; HODGES, T.K. Cell culture and regeneration of transgenic plants. In: KUNG, S., WU, R. (Ed.). Transgenic plants, San Diego: Academic Press, 1983, v.1, p.147-178.

$\mathrm{ROACH}$, B.T.; DANIELS, J. A review of the origin and improvement of sugarcane. In: COOPERSUCAR INTERNATIONAL SUGARCANE WORKSHOP, Sao Paulo: COPERSUCAR, 1987. p.1-31

ROMEIRO, R.S. Bioquímica da interação da bactéria - planta. Viçosa: Editora UFV, 1985. p.37.

ROMEIRO, R.S. Fundamentos de Fisiologia do Parasitismo em Fitopatologia., Ed.UFV, Viçosa. 1987, p.31

ROMEIRO, R.S.; KIMURA, O. Inducet resistance in pepper leaves infiltrated with purified elicitors from Xanthomonas campestris pv. Vesicatoria. Journal of Phytopathology, v.145, p.495-498, 1997.

RUSSEL, J. A.; ROY, M. K.; SANFORD, J. C. Physical trauma and tungsten toxicity reduce the efficiency of biolistic transformation. Plant Physiology, v.98, p.1050-1056, 1992.

SAMAC, D. A.; SHAH, D. M. Developmental and pathogen-induced activation of the Arabdopsis acidic chitinase promoter. Plant Cell, v.3, p.1063-1072, 1991. 
SANFORD, J. C.; KLEIN, T. M.; WOLF, E. D.; ALLEN, N. Delivery of substances into cells and tissues using a particle bombardment process. Journal Particle Science Technology, v. 5, p. 27-37, 1987.

SANGUINO, A.; CARDOSO, C.O.N.; CAMPOS, J.D.P.; AMORIM, L.; SILVA, W.M. Constatação da Ferrugem da cana-de-açúcar no Estado de São Paulo. Summa Phytopatologica, v.13, n 1/2, p.44, 1987.

SGRILLO, R.B. Desenvolvimento de modelo matemático para população da broca da cana-de-açúcar, Diatrea sacharalis (Fabr., 1794) e simulação da técnica do individuo estéril. Piracicaba, 1979. 189p. Tese (Doutorado) Escola Superior de Agricultura "Luiz de Qeiroz", Universidade de São Paulo.

SMITH, E.F.; TOWNSEND, C.O. A plant-tumor of bacterial origin. Science, v.25, p.671-673, 1907.

SMITH, F.D.; HARPENDINDING, P.R.; SANFORD, J.C. Biolistic transformation of prokaryotes: factors that affect biolistic transformation of very small cells. Journal of General Microbiology, v.138, p.239-248, 1992.

SORDI, R. A.; MASUDA, Y.; AGUILLERA, M.M.; MARTINS, S.; MATSUOKA, S. A. Ferrugem da cana-de-açúcar no Brasil. Brasil Açucareiro,v.104, n.5/6, p. $6-13,1986$

SORDI, R. A,; MATSUOKA,S.; MASUDA, Y.; AGUILLERA,M.M.; ABRAMO FILHO, J. Principais doenças da cana-de-açúcar na região centro sul do Brasil: curso para engenheiros agrônomos. Araras: UFSCAR, 1988. 77p. 
SOUZA, G. M.; SIMÕES, A.C.Q.; OLIVEIRA, K.C.; GARAY, H.M.; FIORINI, L.C.; GOMES, F.S.; NISHIYAMA JUNIOR, M.Y.; da SILVA, A.M. The sugarcane signal transduction (SUCAST) catalogue: prospecting signal transduction in sugarcane. Genetics and Molecular Biology, v.24, p.25-34, 2001.

STEWARD, F.C.; MAPES, M.O.; MEARS, K. Growth and organized development of cultured cells organization in cultures from freely suspended cells. American Journal of Botany, v.45, p.705-708, 1958.

STICHER, L., MAUCH MANI, B.; METRAUX, J. P. Systemic acquired resistance. Annual Review of Phytopathology, v.35, p.235-270, 1997.

STUPIELLO, J.P. A cana-de-açúcar como matéria-prima. In: PARANHOS, S.B. (Ed.). Cana-de-açúcar: cultivo e utilização. Campinas: Fundação Cargill, 1987. v.2, p.187-259.

SULLIVAN, F. K.; KAY, A. S. Green fluorescent proteins: Methods in Cell Biology, Academic Press, v.58, 1999.

TAYLOR, P.W.J.; ADKINS, S. W.; IMRIE, B. C. Tissue cultures techniques for gene transfer into sugarcane. Focused plant improvement In: AUSTRALIAN PLANT BREEDING CONFERENCE 10., Australia, 1993. Proceedings, Australia: s. Ed, 1993. p. 225-228

TAYLOR, P. W. J.; KO, H.L.; ADKINS, S. W. Factors affecting protoplast isolation and the regeneration of shoot-like structures from protoplast derived callus of sugar cane. Australian Journal of Botany, v. 40, n.6, p. 863-876, 1992. 
TAYLOR, P. W. J.; KO, H.L.; ADKINS, S. W.; RATHUS, C.; BIRCH, R.G. Establishment of embryogenic callus and high protoplast yielding from suspension cultures of sugarcane. Plant Cell, Tissue and Organ Culture, v. 28, n.1, p. 67-78, 1992.

TAYLOR, P. W.J.; GEIJSKES, J.R.; KO, H. L.; FRASER, T. A.; HENRY, R. J.; $\mathrm{BIRCH}, \mathrm{R}$. G. Sensitivity of random amplified polymorphic DNA analysis to detect genetic change in sugar cane during tissue culture. Theoretical and Applied Genetics, v. 90, n.7-8, p. 1169-1173, 1995.

TOMIYAMA, K. Physiology and biochemistry of disease resistance of plants. Annual Review of Phytopathology, v.1, p.295-324, 1963.

TOONEN, M.A.J.; SCHMIDT, E.D.L.; DE VRIES, S.C. Cell tracking as a tool to study initial processes in somatic embryo development. Plant Tissue Culture and Biotechnology, v.2, p.3-10, 1996.

TREWAVAS, A. Signal perception and transduction. In: BUCHANAN, B.B.; GRUISSEM, W.; JONES, R.L. (Ed.) Biochemistry and molecular biology of plants. Maryland USA: American Society of Plants Physiologists, 2001. p.930 - 987.

URBANO, L. A.; SHERMAN, J. M.; MOYER, J. W.; DAUB, M. E. High frequency shoot regeneration and Agrobacterium-mediated transformation of chrysanthemum (Dendranthema grandiflora). Plant Science, v.98, p.69-79, 1994. 
VAIN, P.; MCULLEN, M. D., FINER, J. J. Osmotic treatment enhances particle bombardment-mediated transient and stable transformation of maize. Plant Cell Reports, v. 12, p. 84-88, 1993.

VETTORE, A.; KEMPER, E.; da SILVA, F.; ARRUDA, P. The libraries made SUCEST. Genetics and Molecular Biology, v.24, p.1-7, 2001.

XU, Y.; CHANG, P.F.L.; LIU, D.; NARASINHAM, M.L.; RAGHOTHAMA, K.G.; HASEGAWA, P.M.; BRESSAN, R.A. Plant defense genes are synergistically induced by ethylene and methyl jasmonate. The Plant Cell, v.6, p.10771085, 1994.

WANG, X.; ZAFIAN, P.; CHOUDHARY, M.; LAWTON, M. The PR5K receptor protein kinase from Arabdopsis thaliana is structurally related to a family of plant defense proteins. Proceedings of the National Academy Science of the USA, v.93, p.2598-2602, 1996.

WEIDE, R.; KOORNNEEF, M.; ZABEL, P. A simple, nondestructive spraying assay for the gene in transgenic tomato plants. Theoretical and Applied Genetics, v.78, p.169-172,1989. 